\title{
ECONOMICS
}

\section{Land Use Policy and Employment Growth- Evidence from China}

by

\section{Qiao Wang}

School of Economics and Management, Southeast University

Xiuyan Liu

School of Economics and Management, Southeast University Sam Hak Kan Tang

Business School, The University of Western Australia and

\section{Cong Du}

School of Economics and Management, Southeast University 
Land Use Policy and Employment Growth- Evidence from China

Qiao Wang ${ }^{\mathrm{a}}$, Xiuyan Liu ${ }^{\mathrm{a}}{ }^{*}$, Sam Hak Kan Tang ${ }^{\mathrm{b}}$, Cong Du ${ }^{\mathrm{a}}$

\begin{abstract}
This paper examines the causal effect of land use policy on employment growth in Chinese cities. We find that a stricter Floor Area Ratio Regulation (FARR) leads to a reduction in employment growth in Chinese cities- a one standard deviation reduction in FARR leads to a concurrent reduction of employment growth by 1.1-1.6 percentage points. More populated cities and labour-intensive manufacturing industries are found to be more severely affected by stricter FARR. Moreover, the effect of a stricter FARR is found to be less pronounced on state-owned firms compared to foreign-owned and privately-owned firms. Our main conclusions are robust to a variety of sensitivity tests, different instruments and alternative estimators. They suggest that imposing a stricter legal FARR incurs considerable employment costs for Chinese cities.
\end{abstract}

JEL classification: R52, R14, R11

Keywords: Land Use Policy; Floor Area Ratio Regulation; Employment Growth; Latitude; Earthquake Protection

[This draft: 28 March 2021]

a. School of Economics and Management, Southeast University, 2 Southeast University Road, Jiangning District, Nanjing, Jiangsu, China.

b. Business School, The University of Western Australia, 35 Stirling Highway, Crawley, Western Australia, Australia.

* Corresponding author, email: ducongseu@163.com 


\section{Introduction}

Most countries in the world have implemented policies to regulate land use (Turner et al., 2014; Duranton and Puga, 2015; Gyourko and Molloy, 2015; Brueckner et al., 2017). These land use policies are designed for regional and city planning, for controlling urban population density, and for driving rapid economic growth in urban centres. It is necessary to implement land use policies when rapid urbanization increases demand for housing, and the intensity of urban land development becomes an important issue (Long et al., 2007). Moreover, rapid urbanization brings forth a number of external negative effects as predicted by standard urban economic theory. Hence, to maintain a high quality of life for urban dwellers, policymakers implement controls on land use to avoid problems such as over-population, over-employment and congestion (Brueckner, 2000). Yet, current policy discussions have largely neglected the negative effect of land use policy on urban development which leads to the understating of the costs of stricter land use regulation (Saks, 2008). In addition, much of the literature on the relationship between land use policy and urban development is focused exclusively on developed countries, in particular the United States. There is thus scant evidence from developing countries around the world on the topic (Gyourko and Molloy, 2015).

Floor Area Ratio Regulation (FARR) is one of the most frequently used instruments by policymakers for regulating land use. It stipulates the maximum gross floor area that can be built upon a parcel of land, and is usually implemented by setting the floor area ratio. FARR, a density control policy, is one of the most important forms of land use regulation in China (Cai et al.,2017). If a region has set a substantially lower FARR compared to other regions, then it can be said that this region has a stringent land density control which likely leads to a reduction in housing supply, high housing prices, and low housing affordability (Annez and Linn, 2010). In addition, a low FARR accelerates the outward expansion of the city boundary, resulting in a longer commute between home and work for city dwellers (Bertaud and Brueckner, 2005). In his study of housing and land development in developing 
countries around the world, Bertaud (2010) has argued that more research on the costs and benefits of FARR is essential for informed discussion on land use policies. Therefore, this paper contributes to the literature by studying the effects of FARR as land use regulation on the employment growth of Chinese cities. Since employment growth is a widely used indicator of urban development and the quality of life in urban economics research, this paper provides new evidence from a developing country on how land use regulation affects urban development.

The marketization of land sales in China only officially began in 2002. Using micro land sales data from 2003 onwards, we construct an index of FARR for Chinese cities to measure land use regulation. However, since government land use regulation and urban development are likely endogenous to each other (Colwell and Sirmans, 1993), the major challenge in this study is to overcome the endogeneity of FARR so that we can estimate the causal effect of FARR on urban development. To do so, we require a natural experiment where we can draw a randomized sample of a large number of rapidly growing cities. This, of course, is difficult if not impossible to achieve in reality. Then, our strategy to overcome the endogeneity issue of FARR is to exploit the geographic characteristics of cities such as latitude and the intensity of earthquake protection as instrumental variables. Using these exogenous geographic variables as instruments for FARR, we can then estimate the local average treatment effect (LATE) of FARR on the employment growth of Chinese cities.

Results from our estimations show that imposing a stricter legal FARR is indeed an important contributor to the decline in employment growth in Chinese cities. If the legal maximum FARR is lowered by one standard deviation, employment growth is estimated to be reduced concurrently by 1.1-1.6 percentage points. Previous studies in the literature of land use policy are more concerned with the housing market and how it is being affected by changes in land use policy (Mayer and Somerville, 2000; Libecap and Lueck, 2011; Turner et al., 2014; Yu, 2019). ${ }^{1}$ As far as we are

\footnotetext{
${ }^{1} \mathrm{Yu}$ (2019) shows that farmland protection regulation as an alternative land use policy can affect urban development.
} 
aware, this is the first study that shows the causal effect of imposing a stricter FARR on employment growth.

To check the robustness of our baseline results, we use an alternative measure of land use policy (actual floor area ratio or AFAR). It can be argued that AFAR is more exogenous than the official legal FARR. Moreover, this paper examines how land use policy affects the employment growth of different sized cities and types of firms. We find that the employment growth of more populated cities is greater affected by FARR than that of less populated cities. Also, the effect of a reduction in the legal FARR on employment growth is more pronounced for labour-intensive industries compared to non-labour-intensive industries and for privately-owned and foreign-owned enterprises compared to state-owned enterprises. In addition, we use different estimation methods such as LIML, GMM, control function and plausibly exogenous to conduct robustness checks of our baseline results. It is reassuring that all these robustness checks do not change the main conclusions of this paper.

This paper contributes to the current literature on the relationship between land use regulation and urban development in the following ways. Firstly, this paper examines the causal effect of FARR on employment growth in Chinese cites, thus providing new evidence from a large developing country. Secondly, this paper overcomes the difficulty of measuring land use regulation consistently across Chinese cities since FARR is a representative and consistent measure of land use regulation for all Chinese cities. Thirdly, this paper purges the endogeneity of FARR by using two geographic characteristics of Chinese cities as instruments. These two geographic instruments enables us to estimate the causal effect of land use regulation on employment growth. Fourthly, unlike other studies that focus on the effect of regulation on the housing market, this paper instead looks at how employment growth in Chinese cities is affected by land use regulation, thus giving new evidence on the relationship between land use policy and urban development.

The remainder of this paper is organized in the following way: Section 2 reviews the literature on land use regulation; Section 3 discusses both the background 
of land use policy in China and a brief theoretical analysis of the relationship between land use regulation and employment growth; Section 4 describes the design of the empirical approach including the construction of variables and estimation techniques; Section 5 presents and interprets the estimation results and Section 6 concludes.

\section{Literature Review}

Scholars in urban economics, housing economics and public finance have been studying issues relating to land use regulation. There are two streams of literature relevant to the present paper: one is related to the measurement and the other is related to the effects of land use regulation. In this section, the relevant areas of literature on land use regulation will be systematically discussed.

\subsection{Measurement of Land Use Regulation}

Land use regulation falls usually inside the domain of regional governments. As such, there is a high degree of discrepancies in land use regulation from region to region, which posts a daunting task for researchers in the field to come up with a consistent measure across regions. The difficulties of measuring land use regulation are specifically challenging due to their multifaceted and dynamic natures. Currently, there are three measurement methods of land use regulation.

(1) Indirect regulation tax: According to the new classical school of economics, the market price and marginal cost are equal under perfect competition. Glaeser et al. (2005) argue that the wedge between the market price and marginal construction cost can be used as a proxy for measuring the degree of regulation in the housing market. In their study of Manhattan’s housing market, they use the wedge between the market price and marginal construction cost as an indicator of land use regulation which they referred to "regulation tax". The advantage of using the regulation tax as a measure of land use regulation is that it avoids the difficulties of directly measuring and comparing land use regulations across regions. Rather it relies on economic theory to provide an indirect measure of land use regulation. The 
disadvantage is that marginal construction cost can be difficult to obtain, limiting the applicability of this approach (Gyourko and Molloy, 2015).

(2) An index of unified land use regulation: This approach is based on surveys of people living in a location to come up with a widely acceptable method of measurement of land use regulation. Researchers can then construct an appropriate index of land use regulation based on this widely acceptable method (Glaser et al., 2006a; Gyourko et al., 2008; Gyourko and Molloy, 2015). However, because land use regulation can be very different in different regions, researchers often have to choose between the depth and detail or the quantity of the sample observations. For example, Glaeser et al. (2006a) focuses on examining the greater metropolitan areas of Boston to collect detailed data on environment regulation. By contrast, Gyourko et al. (2008) are more concerned with the comprehensiveness of data coverage in their study. Their measure of the local regulatory environment for housing markets cover 290 cities in 50 states of the US. These two studies provide a classic example of the two contrasting types of measures for land use regulation, one favouring detailed information and the other favouring comprehensiveness of data coverage. ${ }^{2}$ Each measure has its advantage. In particular, the Wharton Residential Land Use Regulatory Index (WRLURI), devised by Gyourko et al. (2008), has been widely adopted in the research of the US housing markets.

(3) A single measure of land use regulation: This approach attempts to reduce the costs of constructing a unified measure of land use regulation. Instead, it focuses only on one particular aspect of regulation such as the expansion of city boundary (Cunningham, 2007), the minimum land plot area (Thorsnes, 2000), the amount of time required for obtaining approval from regional governments (Mayer and Somerville, 2000), and regulations on density or height of residential housing

\footnotetext{
2 To construct their regulatory indicator, Glaeser et al. (2006a) conducted a detailed survey consisting more than 100 questions to collect information on environmental land use control from 187 communities in the Boston metropolitan area. By contrast, Gyourko et al. (2008) constructed a regulatory index based on the answers to three sets of questions in a survey that covered 293 different metropolitan areas in all 50 states.
} 
(Rothwell and Massey, 2010; Fesselmeyer and Seah, 2018; Brueckner and Singh, 2020). Furthermore, Saiz (2010) finds that geography is a key factor in contemporary US urban development. Housing supply in the US is constrained by both physical (steep-sloped terrain) and regulatory environments.

\subsection{The Effects of Land Use Regulation}

Although researchers have paid much attention to the measurement of land use regulation, their key concern lies in the potential impacts of land use regulation on the economy. In this literature, the majority of studies focus on investigating the effects of land use regulation on the housing market. These studies take land use regulation as one of the most important factors in housing supply, drawing the conclusion that housing price and the quantity of housing supply are affected by land use regulation. Specifically, stricter land use regulatory environment will reduce the elasticity of housing supply, thus pushing up rent and housing price as well as reducing new housing constructions (Gyourko and Molloy, 2015; Fesselmeyer and Seah, 2018). Unfortunately, a limitation of these studies is their use of cross-sectional data which do not account for the non-randomness of land use regulation in different regions, and thus making it difficult to draw any firm conclusion on the causal effect of land use regulation on the housing market.

Glaeser and Ward (2009) overcome the endogeneity of land use regulation by using a panel data of restrictions on building construction, but adopting their approach is difficult due to data constraint. Ihlanfelt (2007) employs the instrumental variable approach to identify the causal effect of land use regulation. An appropriate instrument for land use regulation enables researchers to avoid the endogeneity of land use regulation inherent in cross-sectional data. In addition, given that workers usually live close to where they work, land use regulation can affect the workings of the local labour market. Studies such as Glaeser et al. (2006b) and Saks (2008) examine the effects of land use regulation on the labour market. They find that stricter land use regulatory environment results in a lower employment growth in urban 
centres, leading to higher housing prices and wages. In particular, different land use restrictions can give rise to different forms of urban development: Restrictions on height and minimum land plot area result in the expansion of city size and city boundary. In contrast, restrictions on the quantity of building permits can reduce the growth of city size (Bertaud and Brueckner, 2005; Geshkow and Desalvo, 2012). Moreover, land use regulation can indirectly affect families and communities living in cities through its effects on people of different income groups, races or other characteristics (Kahn et al. 2010; Quigley et al. 2004). Some researchers have also started to ponder land use regulation and its effects on social welfare. Turner et al. (2014) decompose land use regulation into three different components and estimate the causal effect of land use regulation on land value and social welfare using this decomposition. Their results show a negative effect of land use regulation on land value and social welfare.

\subsection{Land Use Regulation in Developing Countries}

Thus far, existing studies on land use regulation found in the literature have mainly focused on the US. Although researchers have now began to look at the experience of developing countries, there is still, on the whole, a shortage of studies on the topic of land use regulation from the perspective of a developing country. Lall et al. (2007) study the effect of land use and zoning regulations on Brazil's housing supply. They find that relaxing the restriction on minimum land plot area can significantly increase housing supply. Hannah et al. (1993) find that imposing a restriction on city size can significantly reduce the availability of land supply for housing which sharply increases housing prices in South Korea. Bertaud and Brueckner (2005) and Brueckner and Sridhar (2012) use a theoretical and empirical approach respectively to analyse the effect of FARR on the change of city size in India. They find indirectly that relaxing FARR has the benefit of increased social welfare. Since the study of Fu and Somerville (2001) looks at the effect of FARR in Shanghai, the role played by FARR in Chinese cities has received increasing attention 
(Cai et al., 2017; Brueckner et al., 2017; Tan et al., 2020). This paper is closely related to this stream of previous studies.

In conclusion: (1) a unified index is seen as the most appropriate indicator of land use regulation in the literature, but it involves costly survey data that can be difficult to collect. Hence, a measure that focuses on only one aspect of land use regulation is acceptable when data is readily available for different regions; (2) measures of land use regulation are usually cross-sectional rather than panel data which make it difficult to evaluate the causal effect; (3) most of the previous studies that look at the effect of land use regulation are concerned with the housing market only with little attention paid to issues such as the labour market and productivity growth.

\section{Institutional Background and a Theoretical Model}

\subsection{Institutional Background}

Land use regulation or land use management refers to a set of legislations or laws that manages or controls the supply and utilization of land. It first appeared in Germany and the US in the 19th century. Currently, most of the developed countries have already implemented land use regulation that governs mainly zoning restrictions

in cities and preservation of farmland in rural areas. In China, the legal status of land use regulation started relatively late in 1986 and 1989 when "Laws on Land Management" and "Laws on City Planning” became effective. Currently, land use regulations in China are formulated primarily through the overall general land use policies and are supplemented by detailed annual land use plans. A series of land use indicators are then set as targets for implementation of the series of general policies and detailed plans. Specifically, the Chinese central government formulates the general core land use policies for the entire country which then channel through the provincial governments to relay to governments at the city level. There are three aspects of land use policies at the city level: the farmland appropriation regulation, 
land supply regulation, and land use development regulation. ${ }^{3}$ The narrow definition of land use regulation refers to land use development regulation, which mainly targets the use of land for development of residential housing. We in this paper focus on the land use development regulation, which encompasses regulations such as the maximum FARR, green ratio, approval time for land construction plan permits, and approval time for commencement of construction work permits. Studies such as Cai et al. (2017) and Brueckner et al. (2017) argue that FARR is one of the most important forms of land use regulation in China. Given data on FARR is readily available for most regions in China, this paper examines China’s land use regulation from the perspective of FARR. In particular, it focuses on how employment growth in Chinese cities is affected by regional governments' FARR, which is an instrument that controls the development of residential housing.

In China, FARR provides an important indicator of the degree of land use control by city planners. The core control instrument is the legally stipulated FARR. Because FARR is equal to the gross floor area divided by the area of the land plot, FARR can be viewed as a building height restriction from the civil engineering perspective (Bertaud and Brueckner, 2005). To further control the height of buildings, local governments also set the maximum height when they set the legal FARR. Since 1994, Chinese government officially incorporates the legal FARR in the "Planning Regulations for Urban Residential Areas”, which not only confirms the legal status of FARR, but also establishes FARR as the main instrument of control in any detailed blueprint of urban planning in China. Thus, the effects of FARR on urban development are substantial. According to "Laws of Urban-Rural Planning”, any parcel of land that is being sold for development is subject to a legally FARR (Cai et

\footnotetext{
${ }^{3}$ In general, farmland appropriation regulation aims at preservation of farmland, limiting the appropriation of farmland for development by the regional governments. Land supply regulation includes two aspects: quantity and structure. The quantity aspect includes detailed annual land use plans that set the maximum amount of new land that can be developed by the regional governments, which effectively limits the quantity of land that can be sold to developers by the regional governments. The structure aspect controls the types of development of new land (commercial, residential or industrial).
} 
al., 2017). For implementation, each city draws up a detailed planning blueprint (the so-called "Regulation Blueprint") that requires the approval from the regional administration (Liu et al., 2019). Specifically, this process incorporates three elements: (1) Basing on the decisions of the land supply office, city planners draft the legal FARR which is then to be announced to the public for consultation. After consultation, the drafted FARR is required to seek approvals from higher level governments, and once approvals are obtained the drafted FARR becomes legally binding along with a series of other restrictions on land development. (2) For every parcel of land to be sold, regional governments have to confirm the legal FARR indicator basing on the Regulation Blueprint. Then, land can be sold to the developers by quotation, tender or auction with the legal FARR indicator as an important condition of any sales contracts. At this point, the legal FARR indicator becomes a required engineering specification of a construction project. (3) During the design and construction phases, the city planning bureaus ensure that the legal FARR requirement for the construction project is strictly adhered to by the developers. Also, complying with the legal FARR is a condition for passing the engineering inspection when the construction project is finished. Although some developers have the intention of building over the limit set by the legal FARR, they are required to submit a revision plan which can involve substantial delay in construction as any revision requires approval from the regional governments (Cai et al., 2017).

When land is sold to developers for housing development by regional governments in a competitive market, both parties engage each other with the intention of optimising their own benefits. Given the land price and construction costs, developers intend to raise their profit by building more housing units upon the parcels of land they purchased. As such, they want a higher legal FARR as it would allow them to increase the buildable housing area on a parcel of land and thus increase their own profit. However, land sales market in China is a seller's market where regional governments have the authority to set the legal FARR which developers must adhere to. In general, regional governments set a legal FARR which 
is lower than developers’ desirable FARR (Brueckner et al., 2017; Liu et al., 2019). There are two main conflicting considerations when setting the legal FARR for regional governments. On one hand, regional governments have the interest in setting a higher legal FARR as it increases their revenue from land sales. Since the decentralised tax system reform in 1994, land sales have become an increasingly important source of non-budgetary revenue for regional governments (Zhang et al., 2011). When the area of land is fixed, the housing unit price increases with the land price. For regional governments, increasing the legal FARR can increase the value of land sold as long as the legal FARR is below developers' desirable FARR. Regional governments are then able to raise their revenue from land sales when land value is higher. Thus, both the developers and regional governments share the incentive to set a higher legal FARR. On the other hand, a key concern of regional governments is to control overpopulation and congestion in urban areas which not only reduce the quality of life for urban residents, but also requires regional governments to increase spending on infrastructure and amenities in urban areas (Brueckner, 2000). It is well known in the literature of urban economics that the urban development brings along a number of negative externalities which policymakers need to internalise (Boyce, 1963). Consequently, regional governments need to consider the negative effects of a higher legal FARR such as increasing population density and congestion in urban areas. Thus, for regional governments, they face a trade-off between raising revenue from land sales and increasing spending on infrastructure and amenities when they set the legal FARR.

It is worthwhile to note that if there is a well-functioning housing market, market information provides important signals for regional governments to set an appropriate legal FARR. However, if the housing market is not well-functioning, then regional governments will completely control every aspect of land sales including the legal FARR with little regard to the housing market demand. This may lead to over restrictive land use regulations. For example, policymakers may tend to favour low FARR and low population density for maintaining existing urban architectural design 
without regard to the demand for housing in the housing market. It has been pointed out by some studies that urban planners in India tend to keep urban density low as a key priority (Brueckner and Sridhar, 2012). In some cities, in particular large cities, where housing markets are not well functioning, urban planners tend to overstate the negative externalities of high urban density which results in a lower legal FARR being set. In addition, regional governments may also need to incur a higher cost of building urban infrastructure when these infrastructure projects are built by public rather than private firms. A higher cost of building urban infrastructure further incentivizes urban planners to set an even more restrictive legal FARR. It should be emphasized here is that urban planners often ignore the housing market which plays an important role in affecting the relationship between the planning and implementation of the FARR on one hand and the growth of cities on the other (Glaeser et al., 2006b). In the next section, we will examine the effects of legal FARR on employment from the perspective of housing supply.

\subsection{Theoretical Arguments for the Effects of FARR Regulation on Employment} Growth

Tighter FARR restricts the ability of developers to build more housing units and thus reduces the housing supply. The main effects of the FARR are the following: (1) A higher FARR allows more housing units to be built on a parcel of land which in turn lowers the marginal cost of land and leads to more housing developments (Saks, 2008). (2) The legal FARR stipulates the maximum buildable area on a parcel of land. Since the amount of land available for housing developments is limited, housing supply will be severely curtailed if the legal FARR is set too low (Bertaud and Brueckner, 2005; Barr and Cohen, 2014). (3) Obtaining approval for FARR compliance can delay housing development. For every stage of a housing development, compliance of the FARR is closely monitored by the City Planning Bureau. In particular, a housing development must pass the inspection for meeting the FARR at the completion stage before sales can take place (Cai et al., 2017). All of the 
three effects of the FARR discussed above impose restrictions on developers' ability to start housing developments which in turn reduces the supply of new housing units and makes the housing supply less elastic. Hence, the FARR can lead to adverse consequences for housing supply.

Housing supply is a crucial factor in determining the development of the labour market in cities. For local enterprises to expand the scale of their production, they need to recruit new workers. However, if housing shortages in a city prevent new workers to relocate, the ability of local enterprises to expand their production will be severely restricted. The relationship between the elasticity of housing supply and the mobility of the labour force can be explained theoretically using a simple supply and demand model.

Suppose that labour is perfectly mobile and that the housing market in every city is in equilibrium. Under these assumptions, workers should receive similar wages and benefits regardless of which city they live in. To simplify our discussion, we can further assume that every individual worker lives in an individual housing unit, thus equating the total number of workers in a city, LN, with the number of housing units, $\mathrm{HN}$, in the city. If a city experiences an exogenous productivity shock, the level of technology will be increased for firms in the city. It will lead to an increase in the demand for labour by firms. Moreover, the nominal wage for workers in the city will rise, attracting new workers from elsewhere to come to the city and increasing the demand for housing, thus forming a temporary disequilibrium in the housing market (Desmet and Rossi-hansberg, 2013). Consequently, the house price in the city will be pushed up. Figure 1 illustrates the higher house price (new HP) and the higher number of workers (new LN) when an exogenous productivity shock shifts the demand for housing outward.

[Insert Figure 1 and 2 around here]

Since the housing market in every city is subject to a different set of natural and policy restrictions, the elasticity of housing supply is different from city to city (Saiz, 2010; Gyourko and Molloy, 2015; Liu et al., 2019). Figure 2 illustrates a case 
where housing supply is less elastic in City A compared to that in City B as shown by the steeper upward-sloping housing supply curve for City A compared to that of City B. Suppose that an exogenous productivity shock occurs to both City A and B. As discussed above, an exogenous productivity shock leads to an increase in the demand for housing which then leads to increases in both new workers and house price. Because City A's housing supply is less elastic, making it less able to absorb the increased demand for housing by new workers. Therefore, the increase in house price in City A is higher than that in City B. Also, the increase in the number of new workers in City A is lower than that in City B. On the contrary, City B is able to absorb more new workers into the city and also has a more moderate increase in house price because its housing supply is more elastic. Moreover, a more elastic housing supply ensures more new workers to be able to relocate and work in the city, thus keeping wage relatively stable. Firms in City A, however, have to pay a much higher wage to workers to compensate them for the substantial increase in house price after a productivity shock. Thus, for cities facing low elasticity of housing supply, a productivity shock results in much higher house prices and wages, but not in increases in workers and population (Glaeser et al., 2006b). On the whole, FARR reduces the supply of housing units that restricts mobility of the labour force, thus adversely affecting the growth and employment of the cities.

\section{Construction of Indicators and Empirical Model}

In China, land sales in cities have been allowed since May 2002. ${ }^{4}$ Thus, we are able to extend the sample period back to 2003, and adopt a common sample period of 2003-2013 for all samples used in the analysis. ${ }^{5}$ Also, because the FARR is applicable only for urban areas, the samples include prefecture cities or the higher-level city

\footnotetext{
${ }^{4}$ In May 2002, Department of Land Resources announced that all land uses for commercial, travel, entertainment, and residential housing must be sold by tendered, auctioned, or listed from July 2002 onwards.

${ }^{5}$ In some of the heterogeneity analyses, we use the Database for China's Industrial Corporations to calculate productivity growth. This database includes census data for industrial corporations up to 2013.
} 
districts as the subjects of study. However, it should be noted that many land areas within prefecture cities in China are still non-urban areas, thus making districts more consistent with the concept of urban area than prefecture cities. Moreover, districts in China share many functional characteristics as cities in the United States (Chen, 2010; Desmet and Rossi-Hansberg, 2013).

\subsection{Model Specification}

Rather than focusing on the short-run fluctuations of the FARR, the focus of this paper is to examine the medium- and long-run effects of an increase in the FARR on employment growth. Following the existing literature on urban growth (Duranton and Turner, 2012; Glaeser et al., 2015), we posit the following model of long-run economic growth,

$$
\Delta \ln e m p_{i t}=\alpha+\beta \ln F A R R_{i 0}+\gamma X_{i 0}+\varepsilon_{i}
$$

where the subscripts $i$ and $t$ denote city $i$ and year $t$. Employment is denoted by emp, floor area ratio regulation $F A R R$, a vector of control variables $X$, and the residuals $e$. The dependent variable, $\Delta \operatorname{lnemp}$, is the growth of employment of city $i$ for the sample period 2003-2013. To avoid any potential contemporaneous correlations between employment growth and FARR or between employment growth and a control variable, all right-hand side variables are lagged by one period so that the values of 2002 are used for the right-hand side variables in the regression. ${ }^{6}$ As discussed by Angrist and Pischke (2010), using the lagged right-hand variables mitigates the problem of endogeneity and gives a clearer meaning of the results. The focus of this paper is on the parameter $\beta$ which measures the elasticity of employment growth to changes in FARR, indicating the percentage change of employment growth in response to a one percentage change in FARR.

\footnotetext{
${ }^{6}$ In a robustness test, the main results of this paper remain unchanged when the right-hand side variables are not lagged.
} 


\subsection{Selection of Indicators and Data Sources}

(1) Floor Area Ratio Regulation

Following Sridhar (2010) and Brueckner and Sridhar (2012), this paper uses the average value of maximum FARR of the micro land transactions in a city during the sample period as a measure of the city's regulation on floor area ratio. ${ }^{7}$ That is, the lower the average legal FARR, the stricter is the floor area ratio regulation (Sridhar, 2007). Unlike the study of Brueckner and Sridhar (2012), this paper excludes commercial buildings and includes only residential housing in the study. Because commercial buildings do not provide housing for workers and thus do not constitute housing supply, it is thus appropriate to exclude commercial buildings from the study. In addition, it should be noted that this paper focuses mainly on how the legal FARR affects the employment growth of cities as oppose to the study of Brueckner et al. (2017) which concerns about the stringency of the legal FARR as measured by the gap between the floor area ratio limit set by the government and the market's optimal floor area ratio.

Data on legal FARR are obtained from Chinese Cities’ Micro Land Sales Database. Under the current land sales regulation, all land sales must be subjected to a legal FARR. This paper collects records of 1.38 million land sales transactions from the Micro Land Sales Database between 2003 and 2013. These records contain information from over 200 cities on the geographic location of the land sold, method of sale, legal FARR, land classification, type of land use and the transaction price (Brueckner et al., 2017; Cai et al., 2017). To ensure the sample matches the scope of the study, we restrict the dataset to include only land sales transactions that are located inside city districts, are sold in the private market either by tender, auction or listing, and are residential housing developments. We also omit those land sales transactions that have a missing legal FARR or with a zero legal FARR. Moreover, to

\footnotetext{
${ }^{7}$ As the variation of the legal FARR in each city is extremely small during the sample period, the dataset can be considered as cross-sectional rather than panel. Brueckner and Sridhar (2012) also use a cross-sectional dataset in their study of welfare gains from relaxation of land-use restrictions in India.
} 
avoid the potential effect of outliers, we exclude land sales transactions that are either in the top or bottom one percent of the legal FARR distribution. After the cleanings, the sample contains a total of 59,600 land sales transactions.

[Insert Table 1 around here]

Table 1 shows the legal FARR for major cities around the world. On the whole, the average legal FARR calculated from this paper's sample is consistent with those of Cai et al. (2017). What we observe is that the majority of major cities in China have a legal FARR below 3. Shanghai and Tianjin even have a legal FARR below 2. Major cities in the world such as New York, Tokyo, Singapore, and Hong Kong all have a legal FARR exceeding 10, indicating that these cities have a legal FARR four times higher than those of Chinese cities. It is clear that Chinese cities have a comparatively lower legal FARR which is similar to India, another developing country, studied by Brueckner and Sridhar (2012).

(2) Economic Growth of Cities

Economic growth of a city is measured by the city's employment growth from 2003 to 2013. We calculate employment growth by using the logarithmic difference of employment between 2003 and 2013 ( $\triangle$ lnemp $_{2013}-\triangle$ lnemp $_{2003)}$ ). Employment is the sum of all workers in both public and private firms as well as self-employment. The data is sourced from China City Statistical Yearbook published by the National Statistical Press. We also use each type of employment separately in the regression to check the robustness of the results.

Control Variables

Following the literature on urban growth, this paper adds a host of relevant control variables in the regression that can potentially affect a city's employment growth (Duranton and Turner, 2012; Glaeser et al., 2015; Gyourko and Molloy, 2015). We include the following control variables:

(1) Initial level of employment (lnemp)- diminishing employment growth can be set in when initial employment level is high. We thus control for the initial level of employment and its square. 
(2) Population density (Inpopden)- the higher the population density, the more economic activities there are within and between communities, leading to more employment. We use the density of permanent population at the district level as a measure of population density. Permanent population include both registered residents and temporary residents.

(3) Human capital level (pbachelor)- human capital increases the productivity of the workforce and the scale of economic activity of the city. This paper measures human capital by using the share of population in a district with an education of a bachelor degree or above.

(4) Amenity (amenity)- amenities available in a city can be a crucial factor in attracting workers to that city, especially high-skilled workers (Rosen, 1979). This paper follows the approach of Diamond (2016) in constructing a general index of amenity at the district level that reflects a host of indicators of quality of living in a city. $^{8}$

(5) The housing price (lnHP)- the housing price can reflect the demand for urban housing, which should be highly correlated with the market's optimal floor area ratio as discussed above. Because the market's optimal floor area ratio is a potential covariate of employment growth, adding the housing price as a control in the regression can mitigate the problem of omitted variables. The housing price is measured by the natural logarithms of the average sales price of commercial housing in the city.

(6) The average distance between land parcels and the city centre (Indistance). This variable controls for the effect of land parcels in the sample being unevenly located across the city. The variable is measured by the natural logarithms of the average distance between land parcels and the city centre.

(7) Regions- cities located in different regions of the country (East and Middle) may have their own common characteristics which are not measurable or

\footnotetext{
${ }^{8}$ We selects a total of 18 indicators that can reflect the characteristics of comfort at the city level, and is further divided into three categories that reflect climatic conditions, ecological environment, and medical education and health.
} 
observable. We thus use regional dummies (East and Middle) to control for the potential effects of unobservable characteristics of a region. Except indicated otherwise, the data for all the control variables are collected from China City Statistical Yearbook, China Regional Economic Statistical Yearbook, and the $5^{\text {th }}$ China Population Census. Table 2 shows the summary statistics of the variables included in the regression.

[Insert Table 2 around here]

\subsection{Endogeneity and Instrumental Variables}

Government policies are usually endogenous as they are formulated and implemented for dealing with issues occurring in the country (Colwell and Sirmans, 1993; Brueckner and Sridhar, 2012). Thus, it is reasonable to assume that there is a high degree of endogeneity between the legal FARR and economic growth of cities. The sources of endogeneity are: (1) Reversed causation- cities with a high rate of economic growth experience high employment and population growth rates which lead to congestion and pollution in the cities (Brueckner, 2000). Consequently, regional governments may limit housing supply to control population growth, and imposing a lower legal FARR is an instrument for limiting housing supply in the cities (Gleaser et al., 2005; Brueckner et al., 2012). (2) Omitted variables- although we have added a host of control variables in the regression, there may still be potential covariates of urban economic growth missing from the regression, leading to the issue of endogeneity. (3) Measurement errors- using the average legal FARR calculated from a sample of land sale transactions to measure the actual FARR in a city may result in measurement errors which can also cause endogeneity.

In the absence of a natural experiment or a random selection of cities experiencing rapid economic growth, using instrumental variable becomes a key for tackling the issue of endogeneity (Duranton, 2016). Finding an appropriate instrument for FARR is thus paramount in this study. This paper first attempts to explore historic FARR as an instrument for the current FARR. The problem with this approach is that 
a long history of FARR is unavailable in China because China has only started to use FARR as a management policy for urban centres in the 1980s. Without a long history of FARR, it is difficult to satisfy the condition of exogeneity for an appropriate instrument (Combes and Gobillion, 2015). Therefore, rather than using a historic FARR as an instrument, this paper focuses on exploring the geographic characteristics of cities for instrumenting FARR.

One of the geographic characteristics is the latitude of the city. According to city planning guideline for ensuring a healthy living environment, the interior of every residential housing is required to meet the standard of sunlight exposure. For example, the Central Government’s directive “City Residential Housing Planning Design Regulations” (GB50180-93), announced in 2002, stipulates that the interior of all residential housing under planning must have at least two hours of sunlight exposure during the coldest period of winter (around late January). To meet this sunlight exposure requirement, construction design of residential housing has to take into account of the solar elevation angle and the length of the sun's shadow at noon during the coldest period of winter, and latitude is a determining factor of how the length of sun's shadow varies in different locations (Department of Housing and Urban/Rural Development, 2016; Liu et al. 2019). In general, areas in higher latitudes have a smaller solar elevation angle in the winter which may lead to stricter FARR in those areas to ensure that the two-hour sunlight exposure requirement is met for residential housing. Thus, under the regulation of minimum sunlight exposure for residential housing, cities in Northern China in general have a lower legal FARR compared to that of cities in Southern China. Since the latitude in China from North to South varies more than 50 degrees, this source of exogenous variations of cities makes latitude a potential appropriate instrument for FARR.

Another potential instrument for FARR is the earthquake protection intensity index. Earthquake protection is a basic requirement in any residential housing construction projects. According to the directive "Construction Design Regulations on Earthquake Protection” (GB 50011-2001) of China’s Department of Housing and 
Urban/Rural Development, all buildings built for housing in areas that have been given an earthquake protection intensity index of 6 or above must implement earthquake protection measures. ${ }^{9}$ This paper collects data on earthquake protection intensity index for all city districts, and find that all city districts have an earthquake protection intensity index ranging between 6 and 9. Therefore, residential housing buildings in all city districts are required to implement earthquake protection measures. Those residential housing buildings in areas more prone to serious earthquake are required to implement stringent earthquake protection measures. For example, Tangshan in Hebei and Wenchuan in Sichuan are areas that had experienced serious earthquake disasters and consequently these areas are given an intensity index of 8 compared to the national average of 6.7. Cities located in areas with a high earthquake protection intensity index usually implement more stringent limits on the height and number of floors for residential housing buildings. Thus, there exists a potential relationship between the earthquake protection intensity index and the legal FARR.

\section{[Insert Diagram 3 and 4 around here]}

Diagram 3 and 4 visually illustrate the relationships between FARR and latitude and between FARR and the earthquake protection intensity index. Both diagrams show a clear negative relationship, indicating that higher values of latitude or the earthquake protection intensity index are associated with lower FARR. These close relationships support the use of latitude and the earthquake protection intensity index as instruments for FARR. Furthermore, both latitude and the earthquake protection intensity index are exogenously determined as they reflect the geographic characteristics of cities, and thus meet an important condition of an appropriate instrument. Another important criterion of an appropriate instrument is the exclusion restriction: that is, the only channel through which latitude or the earthquake protection intensity index affects employment growth in cities is FARR, the excluded

\footnotetext{
${ }^{9}$ Seismic fortification intensity is a concept in earthquake engineering, which means that the design of buildings must meet the design requirements of not less than the local basic seismic intensity, which is generally divided into 6, 7, 8, 9 degrees. The larger the value, the higher is the fortification intensity.
} 
instrumented variable. Obviously, there can be other possible channels through which latitude or the earthquake protection intensity index affects employment growth. We thus use a host of controls to take into account of other possible channels (Combes et al., 2010). Another worthy point to note is that there is little correlation between latitude and the earthquake protection intensity index which has a correlation coefficient of only 0.20 , indicating that each of these exogenous geographic characteristics contributes to explaining FARR which leads to smaller standard errors and more precise estimates (Combes and Gobillon, 2015).

\section{Empirical Analysis}

\subsection{Baseline Regression}

Equation (1) provides the analytical framework for estimating the potential relationship between FARR and employment growth in Chinese cities. We first estimate Equation (1) by using the standard OLS estimator and its results are shown in Column 1-3, Table 3. These OLS results show that FARR and employment growth are not significantly related regardless whether any control variables are added into the regressions. As discussed above, the problem with using the OLS estimator is that FARR is likely to be correlated with the error term (or FARR is endogenous).

Endogeneity can be caused by measurement error, simultaneity and omitted variables. These three sources of endogeneity can lead to biased and/or imprecise estimates. Thus, we need to address the issue of endogeneity of FARR.

[Insert Table 3 around here]

To address the issue of endogeneity of FARR, we use the two-stage-leastsquares estimator (2SLS) to estimate Equation (1) again. ${ }^{10}$ The 2 SLS estimator gives a local average treatment effect (LATE) of FARR on employment growth. Our

\footnotetext{
${ }^{10}$ The baseline analysis employs the 2SLS estimator in an instrumental variable approach to estimate the effect of FARR on the employment growth of Chinese cities. To show the robustness of these baseline results, Table 1 of Appendix reports the results of other estimators including limited information maximum likelihood (LIML), generalized method of moments (GMM) and control function method (CFM). These regression results corroborate with those of the baseline analysis that imposing a stricter FARR reduces the employment growth of Chinese cities.
} 
strategy is to employ either one of our two instruments separately or both of the instruments together in the first stage of 2SLS estimations. When two instruments are available, it is possible to check for the robustness of the results using an alternative instrument. However, it is uncommon to find more than one appropriate instrument in a study in the literature of urban economics. Thus, using an alternative instrument in 2SLS estimations is also a valid robustness test (Baum-Snow and Ferreira, 2015).

[Insert Table 4 around here]

Table 4 shows the results of the first-stage regressions. The $P$-values of endogeneity tests in all columns of Table 4 are less than 0.05 , indicating that the null hypothesis of OLS and instrumental variable estimators producing similar results can be rejected, which validates the use of the instrumental variable approach in our study. Furthermore, the F-statistics for the excluded instruments are more than 10, and the maximum 2SLS relative bias reports the minimum bias that reject the null hypothesis that the instruments are weak (Stock and Yogo, 2005), suggesting that both latitude and the intensity index of earthquake protection are not weak instruments of FARR. Also, when we use both instruments in the first-stage regressions, the over-identification tests in Column (3), (6) and (9) show a $P$-value of over 0.05 , allowing us to not reject the null hypothesis that the instruments are valid instruments and that they are correctly excluded from the estimated equation. Reassuringly, all the above diagnostic tests suggest that latitude and intensity index of earthquake protection are appropriate instruments of FARR. Table 4 shows that the estimated coefficients of latitude are negative and statistically significant at the onepercent level: When latitude is increased by one degree, FARR is estimated to decrease by 0.8 to 1.0 percent, suggesting that cities located further north in China have to lower their legal FARR in order to comply with the policy of minimum sunlight exposure for residential housing. The estimated coefficients for the intensity index of earthquake protection indicate that for a one unit increase in the intensity index, the legal FARR is estimated to decrease by 5-8 percent, suggesting that cities are required to lower the legal FARR when they are located in areas more prone to 
earthquakes and thus need to implement stricter earthquake protection measures in residential housing design and construction. In sum, results of the first-stage regressions clearly show that both latitude and the intensity index of earthquake protection are appropriate sources of exogeneity for instrumenting the legal FARR.

Column 4-12, Table 3, show the estimation results of 2SLS estimator. Results in Column 4 are produced using latitude alone as the instrument for the legal FARR, Column 5 using the intensity index alone, and Column 6 using both latitude and the intensity index as instruments. As the results shown, the coefficients of legal FARR are all positive and statistically significant at the conventional levels. The estimated coefficients of FARR are elasticities of the employment growth of Chinese cities with respect to changes in the legal FARR: That is, for every one-percentage point decrease in the legal FARR, employment growth in Chinese cities are estimated to decrease by 1.1 to 1.6 percentage points. This result gives support for our main hypothesis that the legal FARR restricts the growth of employment in cities. Column 7-9 repeat the 2SLS estimations of Column 4-6 but add the control variables of initial employment in the regressions. Results show that adding initial employment in the regressions change little the significance or magnitude of the coefficients of the legal FARR, suggesting the estimated effect of the legal FARR on employment growth is not a result of mean reversion. Column 10-12 further add population density, housing price, amenity, and human capital level into the regressions, and again we find that the coefficients of the legal FARR are robust. Clearly, all the control variables added into the regressions cannot replace the significance of the legal FARR in explaining the employment growth of cities. In the next section, we will be conducting further tests of robustness by employing the specification of Column 12 as the baseline model because it has both latitude and the intensity index as instruments, and also includes a full set of control variables in the regression.

\subsection{Robustness Tests}

\subsubsection{Changing the Core Variables}


In the above baseline analysis, we use the average legal FARR for new land sale transactions in cities as a measure of FARR. Although it appears to be a representative measure of FARR, there are other ways of measuring FARR. We now test whether the baseline results are robust to using alternative measures of FARR. The first alternative measure is the average actual FARR, AFAR, which can be calculated by using per capita living area and the size of population living in the residential land. Duranton (2016) uses this measure of FARR for evaluating the agglomeration effects in Colombia. The second alternative measure of FARR, FARRX, is similar to the average legal FARR except that it includes land sale transactions by contract in addition to transactions by tender, auction or listing. Therefore, FARRX is a broader measure of FARR compared to the average legal FARR. Land reserved for building subsidized housing for low-income families on welfare are generally sold by contract. Owners of these subsidized housing units cannot sell their units on the market for five years, and have to pay a land tax to sell their units after five years on the market. Therefore, land sale transactions by contract can also be considered as market transactions. ${ }^{11}$ The third alternative measure of FARR is the median legal FARR. Using the median rather than the average avoids the potential effects of outliers on the estimation results. In addition to the various measures of FARR, we also use the components of employment (public employment versus private and self-employment) separately as the dependent variable in the regression to check for the robustness of our baseline results.

[Insert Table 5 around here]

Table 5 reports the results of the robustness tests when we change the core variables of the regression. Column 1-3 show the results when AFAR, FARRX and median legal FARR are used respectively as an alternative measure of FARR. The estimated coefficients of alternative measures of FARR are all positive and highly statistically significant, indicating that the baseline finding is unaffected by employing

\footnotetext{
${ }^{11}$ Article 30, “Administrative Measures on Affordable Housing” (Jianzhufang [2007] No. 258) stipulates: "Affordable housing buyers have limited property rights. Purchases of affordable housing for less than 5 years are not allowed to be directly listed for trading."
} 
alternative measures of FARR. Column 4 and 5 show the results when public employment and private employment are used separately as the dependent variable. Again, we find that the effect of the legal FARR on public or private employment growth is still positive and statistically significant. Thus, changing the core variables of the regression has little effect on the baseline conclusion that FARR restricts the employment growth of cities.

\subsubsection{The Validity of Instrumental Variables}

This paper uses the instrumental variable method to identify the impact of land use regulation on urban employment growth. Therefore, using valid instruments is the key to ensuring the credibility of the results. Specifically, our selected instruments must satisfy the conditions of the relevance hypothesis and exclusion restriction. The F-statistics and the maximum 2SLS relative bias test of the first stage regression of the baseline model indicate that the two selected instruments, latitude and the seismic fortification intensity, both meet the relevance hypothesis of a valid instrument. Also, we test the exogeneity of all the instrumental variables using the Basmann's overidentification method as there are more than one instrument in this paper (Glaeser et al., 2015). The results of the over-identification test in the baseline regression confirm that all the instruments meet the condition of exclusion restriction. However, some critics may still have lingering doubts about the exogeneity of the instruments. There may be channels other than the legal FARR through which the instruments affect the employment growth of cities. Firstly, latitude or the seismic fortification intensity may affect employment growth by affecting the industrial structure of cities. Secondly, the intensity of seismic fortification may also directly affect the incentive of enterprises to enter a market, thus having an impact on urban employment growth. Thirdly, latitude is often used as a proxy indicator of regional temperature in the literature of development economics, and thus latitude may directly affect the employment growth of cities.

[Insert Table 6 around here] 
To ensure that the selected instruments in this paper meet the condition of exclusion restriction, we add the control variables of the industrial structure, the number of new entrants, and temperature in the baseline model. The industrial structure is measured by the value added of the secondary and tertiary industries as a share of the regional GDP (secondary and tertiary). The number of new entrants is measured by the growth rate of the enterprises in each city during the sample period ( $\Delta$ lnenterprise) or the natural logarithms of the total number of new enterprises (Innewenterprise). Temperature is measured by the natural logarithms of the winter temperature (lnwintertemp) and the natural logarithms of the summer temperature (Insummertenp). Table 6 reports the regression results after adding the additional control variables. We find that there are no substantial differences in the baseline results after incorporating additional factors that may invalidate the condition of exclusion restriction of our selected instruments. Reassuringly, these results confirm once again that the selected instruments in this paper are valid.

\subsubsection{Additional Instruments}

In the baseline analysis, we employ latitude and the earthquake protection intensity index for instrumenting FARR. Various diagnostic tests show that the two instruments are valid and performing well. However, both of these instruments are geographic characteristics of cities. We are interested in finding an additional instrument for FARR that is not itself based on the geography of cities. This additional instrument is the number of designated historical and cultural sites (DHCS) in a city. There is a negative relationship between the number of DHCS and the FARR in a city: That is, the higher the number of DHCS in a city, the lower is the legal FARR of this city. Because historical and cultural sites represent the history and origin of cities, city planners have a tendency to protect these historical and cultural sites and to maintain a spacious and pleasant environment around these sites. Therefore, areas where these DHCS are located would have a more restrictive FARR. 
Many well-known historical cities in China clearly show a lower average legal FARR. For example, since 1991, Shanghai implemented the "The Methods of Protecting and Managing Premium Historical Buildings in Shanghai”, which clearly states that buildings within the protected area of the DHCS must be subjected to height and size restrictions to preserve the original historical environment. Similar regulations have also been implemented since the 2000s in famous historical cities such as Xian, Wuhan and Beijing. Using this logic, we argue that the average legal FARR decreases as the number of DHCS increases in a city.

We argue that the number of DHCS does not directly affect the growth of employment in cities. Although it is possible that tourism can be linked to the number of DHCS, but this link may be weak. One reason for the weak link is that tourism accounts for only a small share of GDP of most Chinese cities. In contrast, tourism in other developing countries such as Mexico is a major sector of the economy (Faber and Gaubert, 2019). Another reason for the weak link is that tourists are attracted not only by historical and cultural sites but also by natural environment. Thus, there may not be a direct link between the number of DHCS and tourism. We also add the number of DHCS in the regression to explain employment growth, and find that there is no direct link between the two variables as required by the instrumental variable approach.

The State Council of China announced a list of national principle cultural items to be protected in 1961, 1982, 1988, 1996, 2001, 2006 and 2013. For each wave of announcement, we manually compile a data of DHCS that correspond to city districts in the sample. In total, we have 1,494 DHCS. Because the announcements of the first five waves of DHCS occurred before the sample period 2003-2013, there should be little contemporaneous correlation between employment growth and the number of DHCS. However, the last two waves of announcements were made during the sample period, and thus it is possible that the decisions in designating a historical and cultural site might have been affected by employment growth in cities. Furthermore, it is worthy to note that the number of DHCS is relatively small in the 
earlier waves of announcements with some cities not having any DHCS. This may affect the precision of the estimated effect of FARR on employment growth.

[Insert Table 7 around here]

Table 7 reports the estimation results of adding the number of DHCS as an additional instrument in the regressions. Column 1-7 show respectively the results of using the first to seventh wave of DHCS as the additional instrument. We find that in the second-stage regressions the coefficients of FARR are all positive and statistically significant at the conventional levels, providing further support to our baseline conclusion. In the first-stage regressions, however, the results show that the coefficients of DHCS in Column 1-5 are estimated to be negative but statistically insignificant at the conventional levels. Thus, there is some reductive effect of the number of DHCS on FARR but it is generally not strong. The F-statistics for the excluded instruments are over 10 for all columns, indicating that the instruments are strong rather than weak instruments as a whole. In addition, the over-identification test confirms that the instruments in Column 1-5 are valid and properly excluded from the regressions, but fails to confirm the same for Column 6 and 7. The results in Column 6 and 7 may possibly be reflecting the contemporaneous correlation between the decisions to designate historical and cultural sites and employment growth in the 2006 and 2013 waves, thus making the use of the number of DHCS invalid. In sum, we find that the number of DHCS is a weaker instrument compared to latitude and the intensity index of earthquake protection. Its data also imposes certain limitations. Yet, we believe that it provides an interesting and complementary source of exogeneity for instrumenting FARR.

\subsubsection{Additional Control Variables}

In order to conform to the existing literature, we have added a set of variables as standard controls for urban growth in the baseline analysis (Glaeser et al., 2015). There are, however, other variables that can possibly be correlated with employment growth in cities, and we now consider these possible control variables. Urban sprawl 
is a common space management practice for cities under development (Glaeser and Khan, 2004). The general issue is that cities often expand their boundaries in excess of the growth of their population. In many Chinese cities, the expansion of city boundary has been much faster than the growth of city population, leading to rapid urbanization (Qin et al., 2019). As the legal FARR affects the "height” of residential housing buildings and the urban sprawl affects the "size" of area of the city, two options of managing city housing development are available to policymakers (Cai et al., 2017). It is thus likely that these two options, that is, "height” versus "size”, are systematically related to each other.

Another possible covariate of employment growth in cities is the demand for labour. An increase in the demand for labour leads to a higher growth in wages which in turn attracts more migrant workers into the city (Brueckner, 2000). Cities experiencing a higher growth generally have a higher demand for workers, giving rise to higher wage growth, more inflows of migrant workers, and a rapid pace of urbanization. Consequently, labour demand shocks could result in the policymaker to set a stricter FARR. (Gleaser et al., 2006b).

[Insert Table 8 around here]

We include two additional control variables in the regression: city expansion and labour demand shocks. Following Fallah et al. (2012), urban sprawl is measured by a variable Sprawl $=0.5(\mathrm{LA}-\mathrm{HA})+0.5$, where $\mathrm{LA}(\mathrm{HA})$ represents the share of a city's area where the population density is lower (higher) than the average population density of the country. Sprawl ranges from zero to one with the value of one indicating a higher level of city expansion. In addition, we follow Bartik (1991) to calculate labour demand shocks in each city by multiplying the labour shares of different sectors in a city and the corresponding sectoral growth. ${ }^{12}$ Table 8 reports the results of adding Sprawl and Bartik in the baseline regression. We find that the baseline results change little after adding Sprawl or Bartik or both in the regressions;

\footnotetext{
${ }^{12}$ We construct two forms of Bartik index Bartik1 and Bartik2 following Brueckner et al. (2017). The difference between the two indexes is that the latter deducts the overall employment growth rate of cities across the country on the basis of the industry growth rate at the national level.
} 
the coefficient of FARR remains positive and statistically significant at the conventional levels. Reassuringly, our baseline conclusion remains to be valid.

\subsubsection{Mobility of Labour}

Workers have the ability to move to a different city, especially neighbouring cities, to seek a better job and/or a living environment. We now consider that the employment growth of a city may be affected by FARR in the neighbouring cities. If, say, neighbouring cities lower their legal FARR, a city in the vicinity may experience a higher employment growth because workers from its neighbouring cities are more incline to move to that city. Following Hornbeck and Moretti (2018), we calculate the average legal FARR for all the cities within $100 \mathrm{~km}, 200 \mathrm{~km}$ and $300 \mathrm{~km}$ of a city and add this variable, InspatialFARR, as an additional control in the baseline regression. Column 1, Table 9, shows the results when controlling the average legal FARR for neighbouring cities within 100km, Column 2 within $200 \mathrm{~km}$, and Column 3 within $300 \mathrm{~km}$. All three columns show that the coefficients of FARR are positive and statistically significant at the conventional levels, even though their significances are lower than that of the baseline estimate. Our baseline conclusion is thus once again supported by this robustness test exercise. Also, as what we expected, the estimated sign of InspatialFARR is negative and statistically significant in all three columns, indicating that the employment growth of a city decreases when the average legal FARR of its neighbouring cities increases.

[Insert Table 9 around here]

\subsection{Heterogeneity Analysis}

We have shown that lowering average legal FARR reduces employment growth in a city, and this baseline conclusion is robust to a variety of tests. The analysis carried out so far uses aggregate data at the city and employment levels. That is, we have ignored the heterogeneity of cities in terms of their population size, and 
also the heterogeneity of employment in terms of industries and types of firms. We now consider the heterogeneities of cities and employment.

\subsubsection{Population Size}

In China, residence registration (or Hukou) is compulsory for all its citizens who are registered either as a rural or urban resident. Although people with a rural registration are able to work and live in the cities, they are not considered to be urban registered household residents. Therefore, population censuses in China usually distinguish between two different definitions of populations in cities: permanent population and registered household population. We now consider the heterogeneity of city population by adding population, both permanent population and registered household population, in the regression to check the robustness of our baseline conclusion. Moreover, to mitigate the issue of endogeneity between city population and employment growth, we lag city population by one to three years prior to the beginning year (2003) of the sample. Also, we use an interaction variable between FARR and lagged city population to evaluate the effect of FARR on the employment growth of a city conditional on population size. That is, if the estimated coefficient of the interaction variable is positive, then more populated cities would produce a larger effect of FARR on employment growth, suggesting that relaxing the legal FARR results in a higher growth rate of employment for more populated or larger cities.

[Insert Table 10 around here]

Table 10 reports the regression results of controlling for the effect of city population. Column 1, 3 and 5 use the permanent population in the regressions and 2, 4 and 6 the registered household population. Results show that regardless whether city population is lagged one, two or three years, the coefficients of the interaction variable between FARR and lagged city population are all positive and statistically significant, indicating that setting a lower legal FARR results in a reduction in employment growth and this effect is larger for more populated cities. Desmet et al. (2009) provide an explanation for this result: More populated cities experience larger 
agglomeration effects that attract firms coming into these cities. More incoming firms, however, drive up the rental cost for land. Eventually, some firms would have to leave larger cities in order to avoid paying a higher rental cost, and those firms that remain in larger cities would see their profit margin eroded by an increasing rental cost. Consequently, lowering the legal FARR results in a larger reduction in employment growth for firms located in larger cities because these firms face much higher pressure to control costs by cutting employment growth. This finding corroborates those of Saiz (2010) and Liu et al. (2019) that the elasticity of housing supply is smaller for more populated cities.

\subsubsection{Heterogeneities of Industries}

Our baseline analysis focuses only on the aggregate employment growth of a city without looking at employment growth at the sectoral level. Obviously, cities are different in their concentration of manufacturing and services sectors. Some cities may have a high concentration of manufacturing firms while other a high concentration of services firms. Therefore, we want to compare the effect of FARR on the manufacturing sector to that of the services sector. To do that, we first construct a dataset consisting of the employment growth of the manufacturing and services sectors for each city. We also create a dummy variable that takes on one for the manufacturing sector and zero for the services sector, Manudum. To see how FARR affects employment growth in the manufacturing sector compared to that of the services sector, we interact FARR with the dummy variable for the manufacturing sector. Column 1, Table 11, shows the results of the differential effect of FARR on the employment growth of the manufacturing sector compared to that of the services sector. The coefficient of the interaction variable, manudum*InFARR, is 2.2038, which is statistically significance at the one-percent level. This result shows that the employment growth of the manufacturing sector is lower than that of the services sector by 2.20 percentage points for every one percentage point decrease in FARR, 
indicating the greater sensitivity of the manufacturing sector to changes in FARR than that of the services sector.

[Insert Table 11 around here]

Compared to the services sector, firms in the manufacturing sector are more footloose and thus are more sensitive to changes in FARR. Firstly, the manufacturing sector is heavily dependent on electricity as an energy source for production which is readily available across China. Secondly, most manufacturing firms are producing mature products without using advance or high technology. Therefore, these manufacturing firms have little market power and thus are required to accept the prevailing market price for their products. When the legal FARR is lowered, putting upward pressure on rent, a higher rental cost reduces the manufacturing firms’ profit margin even further and thus these firms are likely to relocate their plants (Desmet et al., 2015). In contrast, firms in the services sector are more tied to their existing locations. Firstly, they need to locate near to their customers to provide services to them. Secondly, most firms in the services sector possess a certain degree of product differentiation and thus the market power to set their own price. As a result, these firms in the services sector are able to weather a higher rental cost. When the legal FARR is lowered, putting upward pressure on rent, firms in the services sector are more likely to remain in their existing locations compared to manufacturing firms. Thus, our results reflect the unique characteristics of manufacturing and services sectors in responding to FARR.

Similarly, we examine the differential effect of FARR on employment growth between labour-intensive and non-labour-intensive industries. Column 2 of Table 11 reports that the coefficient of the interaction variable between the dummy variable representing labour-intensive industries and FARR, Labdum*LnFARR, is 1.0853, which is statistically significant at the five-percent level. Thus, firms in labourintensive industries are more sensitive to changes in FARR than firms in non-labourintensive industries. Specifically, a one percentage point drop in the legal FARR leads to an extra 1.0853 percentage point fall in the employment growth of labour-intensive 
industries compared to that of non-labour-intensive industries. This result reflects our earlier discussion that lowering FARR reduces the elasticity of housing supply which leads to an increase in housing price and wage, making it more expensive for firms to hire workers. Firms in labour-intensity industries are thus much more sensitive to changes in FARR than firms in non-labour-intensity industries.

\subsubsection{Corporate Ownerships}

Firms in China can be classified into three different types of ownerships: state owned, privately owned or foreign owned. They can be defined by the percentage share of capital owned by the three different entities (Nie et al., 2014). A firm is defined as state-owned if 50 percent of its capital is owned by the state. A foreignowned firm has at least 25 percent of its capital coming from a foreign country or Hong Kong or Macao or Taiwan (Lu, 2008; Nie et al., 2014). The remaining firms then are classified as privately-owned firms. In order to further compare the impact of FARR on firms of different ownerships, we construct a dataset that includes the employment growth of state-owned, privately-owned and foreign-owned firms in each city. We also construct the dummy variable Privately-owneddum for privately owned firms and the dummy variable Foreign-owneddum for foreign-owned enterprises. In order to understand the differential effects of FARR on the employment growth of firms of different ownerships, we interact FARR with the dummy variables of privately-owned firms and the dummy variable of foreign-owned firms.

Column 3, Table 11, reports the differential effects of FARR on the employment growth of privately-owned and foreign-owned firms compared to that of state-owned firms. The coefficient of the interaction term between privately-owned firms and FARR, Private-owneddum* $\ln F A R R$, is 3.6765 , which is significant at the one-percent level, while the interaction term between foreign-owned firms and FARR, Foreignowneddum*InFARR, is 3.0785, which is significant at the ten-percent level. These results show that the employment growth of privately-owned firms and foreign-owned firms are harder hit by a reduction of FARR compared to state-owned firms. 
Specifically, the employment growth of privately-owned firms is reduced by an extra 3.68 percentage points and foreign-owned firms by 3.08 percentage points compared to state-owned enterprises. Thus, firms which are privately-owned or foreign-owned are much more sensitive to changes in FARR than state-owned firms. The main reason for this phenomenon is that most state-owned firms are supported by the government. In particular, local governments provide subsidies or preferential loans to state-owned firms for the purpose of ensuring GDP and employment to maintain production of stateowned firms ( $\mathrm{Li}$ and Yang, 2018). Therefore, lowering the legal FARR has the smallest impact on the employment of state-owned firms.

\subsubsection{Instrumental Variable Quantile Regression}

Urbanization is uneven across China. Some cities experience a much faster pace of urban growth than other cities. It is intrigue then to find out whether the effect of FARR on employment growth is dependent on the pace of urban growth (Glaeser et al., 2015). That is, cities where employment growth is slow may respond differently to a change in FARR than cities where employment growth is faster. Chernozhukov and Hansen (2006) propose the use of instrumental variable quantile regression (IVQR) to identify the structural quantile function or (conditional) quantile treatment effects. In essence, IVQR allows researchers to apply quantile regression (QR) to capture unobserved heterogeneous effects in policy analysis when the policy itself is endogenous. Since IVQR is a useful tool for policy analysis or program evaluation, we adopt it for analysing the conditional quantile effects of FARR on employment growth.

\section{[Insert Table 12 around here]}

Table 12 reports the results of IVQR. We find that the estimated coefficients of FARR range from 0.4963 to 2.6531, and they are statistically significant at the $0.10,0.15,0.25,0.50$, and 0.75 percentiles, but are not statistically significant at the 0.85 and 0.90 percentiles. These results show that cities where employment growth is slowest experience the largest effect of FARR on employment growth. As 
employment growth increases, the effect of FARR on further employment growth diminishes and eventually becomes non-statistically significant. These results confirm that the effect of FARR on employment growth is heterogeneous and is much more important for cities with a slower employment growth.

\section{Conclusion and Summary}

This paper is the first study that examines the causal effect of FARR on the employment growth of Chinese cities. We find that a reduction of the legal FARR in Chinese cities hinders the growth of employment in these cities. Specifically, a reduction of the legal FARR by one percentage point is estimated to lead to a reduction of employment growth by 1.1 to 1.6 percentage points. Also, more populated cities suffer a lower employment growth when the legal FARR is reduced compared to those cities with a smaller population. In addition, the employment growth of manufacturing industries is more affected by a reduction in the legal FARR compared to that of services industries. Similarly, the effect of a reduction in the legal FARR on employment growth is more pronounced for labour-intensive industries compared to non-labour-intensive industries and for privately-owned and foreignowned enterprises compared to state-owned enterprises.

This study argues that lowering the legal FARR can hinder the employment growth of cities. However, relaxing the legal FARR can also lead to a higher population density that worsens congestion, environmental degradation, and quality of life for city residents. Thus, city planners need to carefully consider the negative impacts of an increase in the legal FARR on the environment and quality of life for city residents. In particular, rather than implementing a comprehensive increase in the legal FARR across the city, city planners can increase the legal FARR for certain residential housing areas, while making sure that the higher population density does not compromise adequate sunlight exposure, parkland area and public space for the urban population. Moreover, an efficient public transportation system and a wellintegrated and functioning road network that reduces traffic congestion are essential. 
Results of this study have policy implications for cities around the world, especially for those cities under rapid development in emerging countries. Our results suggest that setting an overly strict legal FARR can lead to rapid increases in housing price, higher wages and also a loss of allocative efficiency (Hsieh and Moretti, 2019). Thus, relaxing the legal FARR is an appropriate policy recommendation for those cities where development has been constrained by a shortage of housing supply and high rent. Although we have not conducted any detailed cost and benefit analysis on how a city is impacted by a change in the legal FARR, we believe that the current study still contributes to the understanding of the impact of land use policy on urbanization in emerging countries.

One of the shortcomings of the current study is the use of a cross-sectional rather than panel dataset. Although we have used several valid instruments to estimate the causal effect of FARR on employment growth, we are not able to control for any unobserved time-invariant city fixed-effects without a panel dataset. Another shortcoming of the current study is the use of the legal FARR as a measure of land use policy. Obviously, the legal FARR represents only one aspect of land use policy. A more comprehensive measure of land use policy for China, like the WRLURI in the U.S., should be constructed and adopted for studying the causal effect of land use policy in China. These are some of the fertile topics for future research in this area. 


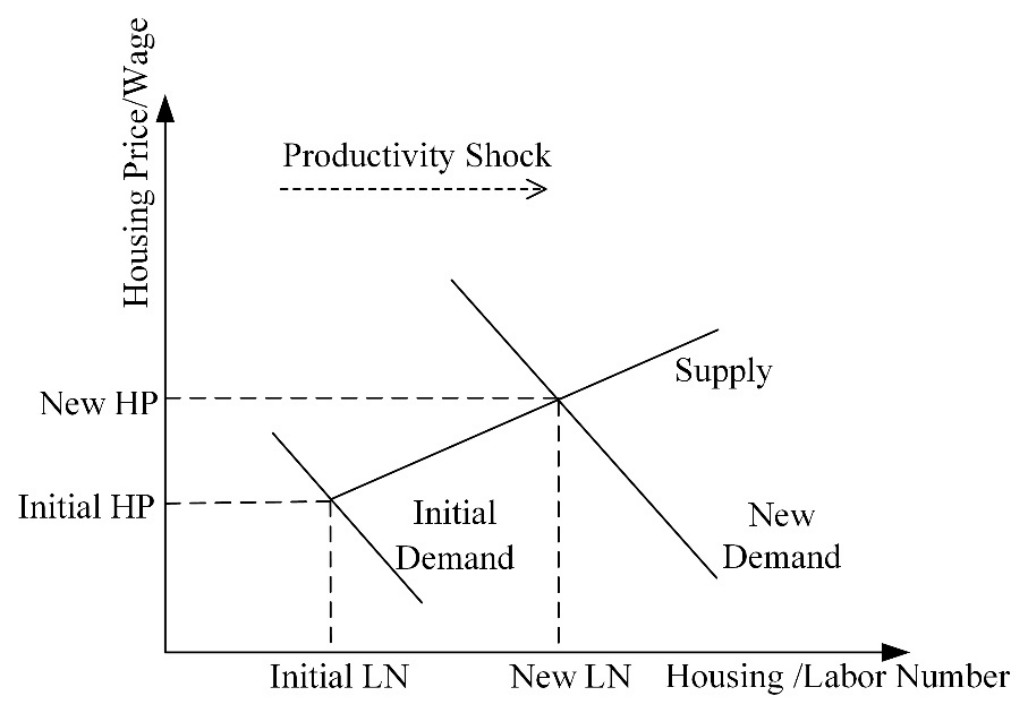

Diagram 1 The impacts of productivity shocks on the housing and labour markets

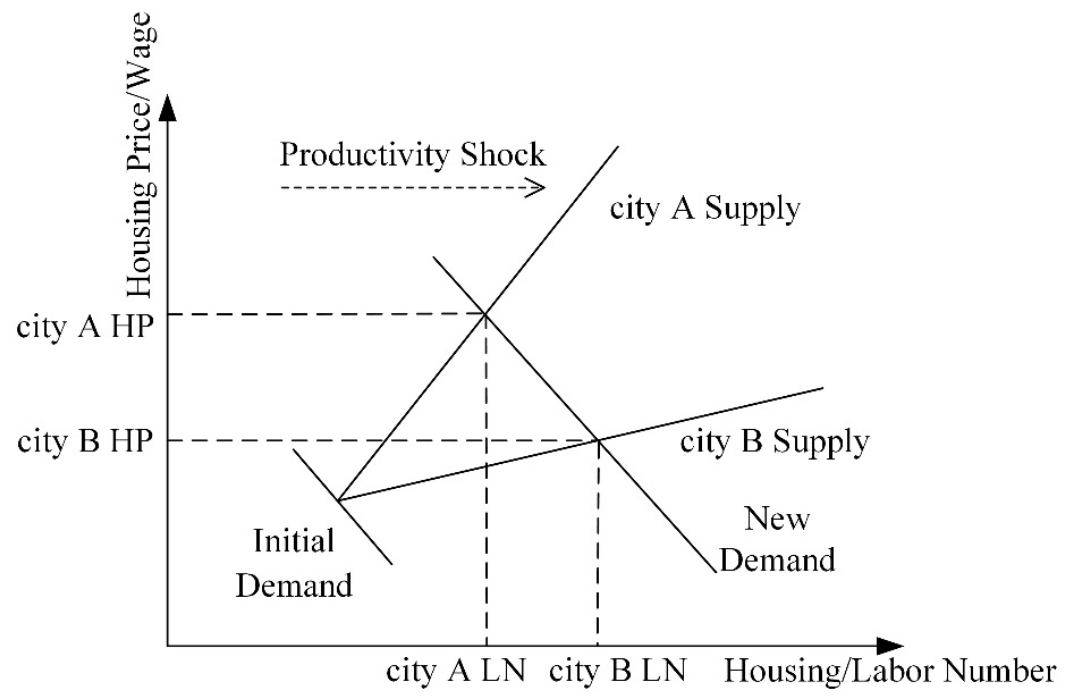

Diagram 2 The impact of productivity shocks on the housing and labour markets in cities with different housing supply elasticities 


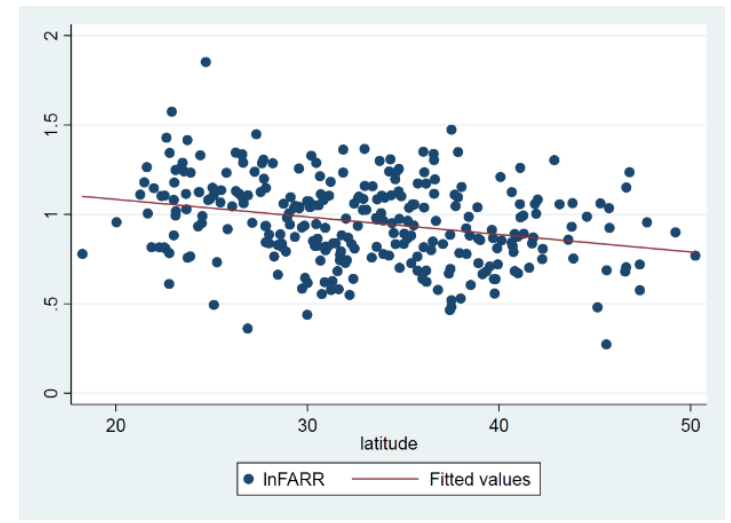

Diagram 3 The correlation between FARR and geographic latitude Notes: The diagram shows a clear negative relationship between FARR and geographic latitude in Chinese cities.

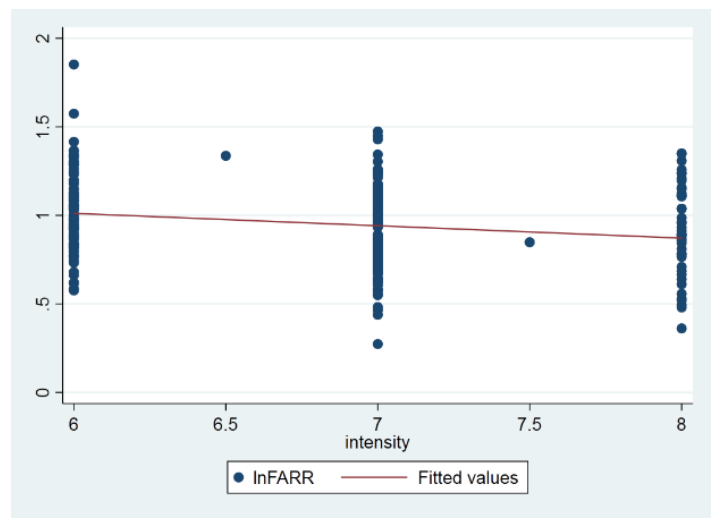

Diagram 4 The correlation between FARR and the seismic fortification intensity Notes: The seismic fortification intensity generally ranges from 6 to 9 degrees. The larger the value, the higher is the fortification intensity. The diagram shows a clear negative relationship between FARR and the seismic fortification intensity. 
Table 1: The average legal FARR of some major cities in China and the world

\begin{tabular}{c|c|c|c|c}
\hline Cities in China & Statistics by Authors & $\begin{array}{c}\text { Statistics of Cai et } \\
\text { al.(2017) }\end{array}$ & Cities in the world & $\begin{array}{c}\text { Statistics by the } \\
\text { World Bank }\end{array}$ \\
\hline Beijing & 2.25 & 2.12 & New York & 15 \\
\hline Shanghai & 1.78 & 1.65 & Los Angeles & 13 \\
\hline Dalian & 2.37 & 2.16 & Tokyo & 20 \\
\hline Hangzhou & 2.34 & 2.28 & Singapore & $12-25$ \\
\hline Chengdu & 3.37 & 3.32 & Hong Kong & 12 \\
\hline Wuxi & 1.98 & 2.03 & Paris & 3 \\
\hline Tianjin & 1.95 & 1.87 & Venice & 2.4 \\
\hline Wuhan & 2.86 & 3.00 & Amsterdam & 1.9 \\
\hline Xi'an & 3.46 & 3.79 & Mumbai & 1.33 \\
\hline
\end{tabular}

Notes: The data for major cities in China come from the author and Cai et al. (2017), and for major cities in the world come from the World Bank (2012).

Table 2: Descriptive statistics of data

\begin{tabular}{lccccc}
\hline Variable & $\begin{array}{l}\text { Number of } \\
\text { samples }\end{array}$ & Mean & Standard deviation & Minimum & Maximum \\
\hline Inemp & 270 & 0.6275 & 0.4540 & -1.2180 & 2.4323 \\
InFARR & 286 & 0.9573 & 0.2350 & 0.2733 & 1.8524 \\
Inemp & 277 & 2.9307 & 0.9291 & 1.2045 & 6.4255 \\
Inpopden & 277 & 6.5576 & 0.9707 & 2.5649 & 9.0614 \\
pbachelor & 287 & 0.0245 & 0.0202 & 0.0013 & 0.1060 \\
amenity & 283 & 0 & 0.7177 & -1.3600 & 3.3836 \\
InHP & 280 & 7.1412 & 0.3986 & 6.0836 & 8.6661 \\
Indistance & 278 & 2.2756 & 0.8272 & 0.4206 & 4.8479 \\
latitude & 287 & 32.8975 & 6.6638 & 18.2542 & 50.2500 \\
intensity & 287 & 6.7770 & 0.6952 & 6 & 8 \\
\hline
\end{tabular}

Notes: Authors' calculations based on China City Statistical Yearbook and China Building Seismic Design Code (GB 50011-2001) which is available at:

http://www.morgain.com/Help/GB50011-2001/CodeForSeismicDesignOfBuldings.htm. 
Table 3: Baseline regression results

\begin{tabular}{|c|c|c|c|c|c|c|c|c|c|c|c|c|}
\hline & (1) & $(2)$ & (3) & (4) & (5) & $(6)$ & (7) & (8) & (9) & (10) & (11) & $(12)$ \\
\hline & OLS & OLS & OLS & IV & IV & IV & IV & IV & IV & IV & IV & IV \\
\hline $\operatorname{lnFARR}$ & $\begin{array}{c}-0.1290 \\
(0.1014)\end{array}$ & $\begin{array}{c}-0.0971 \\
(0.1035)\end{array}$ & $\begin{array}{c}-0.1383 \\
(0.1262)\end{array}$ & $\begin{array}{l}1.6263^{* * *} \\
(0.5327)\end{array}$ & $\begin{array}{c}1.1081^{*} \\
(0.6236)\end{array}$ & $\begin{array}{l}1.4714^{* * *} \\
(0.4620)\end{array}$ & $\begin{array}{l}1.3780^{* * *} \\
(0.4502)\end{array}$ & $\begin{array}{c}1.1287^{*} \\
(0.6259)\end{array}$ & $\begin{array}{l}1.3227^{* * *} \\
(0.4179)\end{array}$ & $\begin{array}{l}1.5713^{* *} \\
(0.6132)\end{array}$ & $\begin{array}{c}1.0338^{*} \\
(0.6130)\end{array}$ & $\begin{array}{c}1.3579^{* * *} \\
(0.5209)\end{array}$ \\
\hline Inemp & & $\begin{array}{c}-0.0535 \\
(0.0340)\end{array}$ & $\begin{array}{c}-0.2443^{* * *} \\
(0.0602)\end{array}$ & & & & $\begin{array}{c}-0.0835^{* *} \\
(0.0423)\end{array}$ & $\begin{array}{c}-0.0784^{*} \\
(0.0400)\end{array}$ & $\begin{array}{c}-0.0823^{* *} \\
(0.0414)\end{array}$ & $\begin{array}{c}-0.2581^{* * * *} \\
(0.0725)\end{array}$ & $\begin{array}{c}-0.2538^{* * * *} \\
(0.0645)\end{array}$ & $\begin{array}{c}-0.2564^{* * * *} \\
(0.0690)\end{array}$ \\
\hline Inpopden & & & $\begin{array}{c}0.0799^{*} \\
(0.0430)\end{array}$ & & & & & & & $\begin{array}{l}-0.0706 \\
(0.0692)\end{array}$ & $\begin{array}{c}-0.0269 \\
(0.0674)\end{array}$ & $\begin{array}{l}-0.0535 \\
(0.0631)\end{array}$ \\
\hline pbachelor & & & $\begin{array}{c}1.5687 \\
(2.4784)\end{array}$ & & & & & & & $\begin{array}{c}3.8308 \\
(2.7144)\end{array}$ & $\begin{array}{c}3.2840 \\
(2.5401)\end{array}$ & $\begin{array}{c}3.6172 \\
(2.6181)\end{array}$ \\
\hline amenity & & & $\begin{array}{l}0.1455^{* * *} \\
(0.0560)\end{array}$ & & & & & & & $\begin{array}{c}0.0829 \\
(0.0752)\end{array}$ & $\begin{array}{c}0.1002 \\
(0.0723)\end{array}$ & $\begin{array}{c}0.0897 \\
(0.0729)\end{array}$ \\
\hline $\ln H P$ & & & $\begin{array}{c}0.1872^{*} \\
(0.1094)\end{array}$ & & & & & & & $\begin{array}{c}0.2235^{*} \\
(0.1235)\end{array}$ & $\begin{array}{c}0.2121^{*} \\
(0.1132)\end{array}$ & $\begin{array}{c}0.2190^{*} \\
(0.1186)\end{array}$ \\
\hline Indistance & & & $\begin{array}{c}0.0253 \\
(0.0383)\end{array}$ & & & & & & & $\begin{array}{l}0.1388^{* *} \\
(0.0589)\end{array}$ & $\begin{array}{c}0.1031^{*} \\
(0.0572)\end{array}$ & $\begin{array}{l}0.1246^{* *} \\
(0.0540)\end{array}$ \\
\hline east & $\begin{array}{c}0.2040^{* * *} \\
(0.0671)\end{array}$ & $\begin{array}{l}0.2661^{* * *} \\
(0.0727)\end{array}$ & $\begin{array}{l}0.1779^{* *} \\
(0.0747)\end{array}$ & $\begin{array}{c}0.4522^{* * *} \\
(0.1105)\end{array}$ & $\begin{array}{c}0.3789^{* * * *} \\
(0.1168)\end{array}$ & $\begin{array}{c}0.4303^{* * *} \\
(0.1036)\end{array}$ & $\begin{array}{c}0.5336^{* * *} \\
(0.1175)\end{array}$ & $\begin{array}{c}0.4884^{* * *} \\
(0.1352)\end{array}$ & $\begin{array}{c}0.5236^{* * *} \\
(0.1118)\end{array}$ & $\begin{array}{c}0.5309^{* * *} \\
(0.1543)\end{array}$ & $\begin{array}{c}0.4199^{* * * *} \\
(0.1505)\end{array}$ & $\begin{array}{c}0.4868^{* * *} \\
(0.1376)\end{array}$ \\
\hline middle & $\begin{array}{c}-0.0399 \\
(0.0609)\end{array}$ & $\begin{array}{l}-0.0015 \\
(0.0620)\end{array}$ & $\begin{array}{c}0.0027 \\
(0.0680)\end{array}$ & $\begin{array}{c}0.0137 \\
(0.0850)\end{array}$ & $\begin{array}{c}-0.0021 \\
(0.0746)\end{array}$ & $\begin{array}{c}0.0090 \\
(0.0811)\end{array}$ & $\begin{array}{c}0.0913 \\
(0.0810)\end{array}$ & $\begin{array}{c}0.0756 \\
(0.0782)\end{array}$ & $\begin{array}{c}0.0878 \\
(0.0786)\end{array}$ & $\begin{array}{c}0.1969^{*} \\
(0.1023)\end{array}$ & $\begin{array}{c}0.1359 \\
(0.0982)\end{array}$ & $\begin{array}{c}0.1727^{*} \\
(0.0937)\end{array}$ \\
\hline _cons & $\begin{array}{c}0.6970^{* * * *} \\
(0.1060)\end{array}$ & $\begin{array}{l}0.7805^{* * *} \\
(0.1457)\end{array}$ & $\begin{array}{l}-0.5553 \\
(0.8243)\end{array}$ & $\begin{array}{c}-1.0887^{* *} \\
(0.5348)\end{array}$ & $\begin{array}{c}-0.5615 \\
(0.6343)\end{array}$ & $\begin{array}{c}-0.9311^{* *} \\
(0.4653)\end{array}$ & $\begin{array}{c}-0.6819 \\
(0.4505)\end{array}$ & $\begin{array}{c}-0.4348 \\
(0.6298)\end{array}$ & $\begin{array}{c}-0.6271 \\
(0.4213)\end{array}$ & $\begin{array}{c}-2.1195^{* *} \\
(1.0310)\end{array}$ & $\begin{array}{l}-1.6277 \\
(0.9992)\end{array}$ & $\begin{array}{c}-1.9243^{* *} \\
(0.9695)\end{array}$ \\
\hline Instrument: & & & & & & & & & & & & \\
\hline latitude & - & - & - & $\mathrm{Y}$ & $\mathrm{N}$ & $\mathrm{Y}$ & $\mathrm{Y}$ & $\mathrm{N}$ & $\mathrm{Y}$ & $\mathrm{Y}$ & $\mathrm{N}$ & $\mathrm{Y}$ \\
\hline intensity & - & - & - & $\mathrm{N}$ & $\mathrm{Y}$ & $\mathrm{Y}$ & $\mathrm{N}$ & $\mathrm{Y}$ & $\mathrm{Y}$ & $\mathrm{N}$ & $\mathrm{Y}$ & $\mathrm{Y}$ \\
\hline Observations & 270 & 264 & 252 & 270 & 270 & 270 & 264 & 264 & 264 & 252 & 252 & 252 \\
\hline $\mathrm{R}^{2}$ & 0.069 & 0.082 & 0.143 & - & - & - & - & - & - & - & - & - \\
\hline
\end{tabular}

Notes: The dependent variable is the change in the log of employment between 2003 and 2013. The coefficient of interest is the natural log of legal FARR.

The estimation method in column (1) - (3) is ordinary least squares (OLS) and in column (4) - (12) is the two-stage least squares (2SLS). The endogenous variable in column (4) - (12) is InFARR which is instrumented by latitude or the seismic fortification intensity. All control variables are in 2002 values.

Robust standard errors are in parentheses. *, ${ }^{* *},{ }^{* * *}$ represent statistical significance at the $10 \%, 5 \%$, and $1 \%$ levels respectively. 
Table 4: First-stage regression results

\begin{tabular}{|c|c|c|c|c|c|c|c|c|c|}
\hline & (1) & $(2)$ & (3) & (4) & (5) & (6) & (7) & (8) & (9) \\
\hline & IV & IV & IV & IV & IV & IV & IV & IV & IV \\
\hline \multirow[t]{2}{*}{ latitude } & $-0.0108^{* * *}$ & & $-0.0092^{* * *}$ & $-0.0120^{* * *}$ & & $-0.0107^{* * *}$ & $-0.0094^{* * *}$ & & $-0.0076^{* * *}$ \\
\hline & $(0.0021)$ & & $(0.0022)$ & $(0.0021)$ & & $(0.0021)$ & $(0.0019)$ & & (0.0019) \\
\hline \multirow[t]{2}{*}{ intensity } & & $-0.0791^{* * *}$ & $-0.0531^{* *}$ & & $-0.0791^{* * *}$ & $-0.0475^{* *}$ & & $-0.0780^{* * *}$ & $-0.0562^{* *}$ \\
\hline & & $(0.0228)$ & $(0.0236)$ & & $(0.0224)$ & $(0.0223)$ & & $(0.0209)$ & $(0.0210)$ \\
\hline \multirow[t]{2}{*}{ _cons } & $1.3621^{* * *}$ & $1.5682^{* * * *}$ & $1.6831^{* * *}$ & $1.3472^{* * *}$ & $1.5027^{* * *}$ & $1.6135^{* * *}$ & $1.3868^{* * *}$ & $1.3868^{* * *}$ & $1.6397^{* * *}$ \\
\hline & $(0.0762)$ & (0.1599) & $(0.1570)$ & $(0.0849)$ & $(0.1573)$ & $(0.1522)$ & $(0.3431)$ & $(0.3491)$ & $(0.3547)$ \\
\hline Control Variables & $\mathrm{Y}$ & $\mathrm{Y}$ & $\mathrm{Y}$ & $\mathrm{Y}$ & $\mathrm{Y}$ & $\mathrm{Y}$ & $\mathrm{Y}$ & Y & $\mathrm{Y}$ \\
\hline First stage sta. & 25.845 & 12.046 & 16.062 & 33.848 & 12.508 & 19.575 & 23.168 & 13.958 & 14.489 \\
\hline maximum 2SLS relative bias & $<10 \%$ & $<15 \%$ & $<15 \%$ & $<10 \%$ & $<15 \%$ & $<15 \%$ & $<10 \%$ & $<15 \%$ & $<15 \%$ \\
\hline Over-id test & - & - & 0.4831 & - & - & 0.7069 & - & - & 0.4339 \\
\hline DWH test & 0.0000 & 0.0093 & 0.0000 & 0.0000 & 0.0149 & 0.0000 & 0.0004 & 0.0194 & 0.0003 \\
\hline Observations & 270 & 270 & 270 & 264 & 264 & 264 & 252 & 252 & 252 \\
\hline
\end{tabular}

Notes: The dependent variable is the natural log of legal FARR. The coefficients of interest are latitude and the seismic fortification intensity. Column (1) (9) of Table 4 correspond to Column (4) - (12) of Table 3, in which the endogenous variable, InFARR, is instrumented by latitude or the seismic fortification intensity or both. All control variables are in 2002 values. Robust standard errors are in parentheses. *, **, *** represent statistical significance at the $10 \%$, $5 \%$, and $1 \%$ levels respectively. 
Table 5: Robustness Test: Changing the core variables

\begin{tabular}{|c|c|c|c|c|c|}
\hline & $(1)$ & $(2)$ & (3) & (4) & (5) \\
\hline & AFAR & FARRX & $\begin{array}{l}\text { Median } \\
\text { FARR }\end{array}$ & $\begin{array}{c}\text { Public } \\
\text { Employment }\end{array}$ & $\begin{array}{c}\text { Private } \\
\text { Employment }\end{array}$ \\
\hline \multirow[t]{2}{*}{$\operatorname{lnFARR}$} & $0.3984^{* * *}$ & $1.3894^{* * *}$ & $1.1540^{* * *}$ & $1.2693^{* * *}$ & $1.6414^{* *}$ \\
\hline & $(0.1432)$ & $(0.5317)$ & $(0.4174)$ & $(0.4900)$ & $(0.7763)$ \\
\hline \multirow[t]{2}{*}{ Inemp } & $-0.2503^{* * *}$ & $-0.2468^{* * *}$ & $-0.2302^{* * *}$ & $-0.2813^{* * *}$ & $-0.3757^{* * *}$ \\
\hline & $(0.0597)$ & $(0.0711)$ & $(0.0694)$ & $(0.0680)$ & $(0.0710)$ \\
\hline \multirow[t]{2}{*}{ Inpopden } & 0.0307 & -0.0407 & -0.0357 & 0.0043 & -0.0489 \\
\hline & $(0.0442)$ & $(0.0672)$ & $(0.0652)$ & $(0.0660)$ & $(0.0817)$ \\
\hline \multirow[t]{2}{*}{ pbachelor } & 4.1993 & 2.9013 & 3.3190 & 2.6985 & 4.1128 \\
\hline & (2.6009) & (2.9115) & $(2.8847)$ & (2.7543) & (3.8085) \\
\hline \multirow[t]{2}{*}{ amenity } & $0.1565^{* * *}$ & 0.0964 & 0.0653 & 0.0895 & $0.1792^{* *}$ \\
\hline & $(0.0586)$ & $(0.0634)$ & $(0.0617)$ & $(0.0631)$ & $(0.0833)$ \\
\hline \multirow[t]{2}{*}{$\ln H P$} & $0.3954^{* * *}$ & 0.1727 & 0.1873 & $0.2944^{* *}$ & 0.1692 \\
\hline & $(0.1286)$ & $(0.1256)$ & $(0.1196)$ & $(0.1265)$ & $(0.1727)$ \\
\hline \multirow[t]{2}{*}{ Indistance } & -0.0042 & $0.1133^{* *}$ & $0.1193^{* *}$ & $0.1243^{* * *}$ & $0.1440^{*}$ \\
\hline & $(0.0447)$ & $(0.0524)$ & $(0.0522)$ & $(0.0482)$ & $(0.0789)$ \\
\hline \multirow[t]{2}{*}{ east } & $0.2887^{* * *}$ & $0.5612^{* * *}$ & $0.4408^{* * *}$ & $0.4369^{* * *}$ & $0.5783^{* * *}$ \\
\hline & $(0.0811)$ & $(0.1575)$ & $(0.1228)$ & $(0.1344)$ & $(0.2069)$ \\
\hline \multirow[t]{2}{*}{ middle } & $0.1522^{*}$ & $0.2312^{* *}$ & $0.1686^{*}$ & 0.0999 & $0.3297^{* *}$ \\
\hline & $(0.0831)$ & $(0.1076)$ & $(0.0920)$ & $(0.0881)$ & $(0.1479)$ \\
\hline \multirow[t]{2}{*}{ _cons } & $-2.0146^{* *}$ & -1.5893 & -1.4086 & $-2.7122^{* * *}$ & -1.7528 \\
\hline & $(0.9012)$ & $(0.9735)$ & $(0.9030)$ & $(0.9767)$ & (1.4125) \\
\hline First-stage stat. & 22.768 & 12.163 & 19.877 & 16.049 & 11.682 \\
\hline maximum 2SLS relative & $<10 \%$ & $<15 \%$ & $<15 \%$ & $<15 \%$ & $<15 \%$ \\
\hline Over-id test & 0.1224 & 0.7020 & 0.8490 & 0.0249 & 0.9896 \\
\hline DWH test & 0.0177 & 0.0007 & 0.0001 & 0.0009 & 0.0070 \\
\hline Observations & 252 & 252 & 252 & 260 & 244 \\
\hline
\end{tabular}

Notes: The dependent variables in columns (1) - (5) are respectively log AFAR, FARRX, Median legal FARR, public and private employment. AFAR is calculated by using per capita living area and the size of population living in the residential land. FARRX is a broader measure of FARR which includes land sale transactions by contract in addition to transactions by tender, auction or listing. The median legal FARR is the median of the legal FARR. Public employment and private employment are the components of employment. The estimation method is the two-stage least squares (2SLS). Robust standard errors are in parentheses. *, **, $* * *$ represent statistical significance at the $10 \%, 5 \%$, and $1 \%$ levels respectively. 
Table 6: Robustness Test: The validity of the instruments

\begin{tabular}{|c|c|c|c|c|}
\hline & (1) & (2) & (3) & (4) \\
\hline & Industrial Structure & Enterprise Entry1 & Enterprise Entry2 & Temperature \\
\hline \multirow[t]{2}{*}{$\ln F A R R$} & $1.3808^{* * *}$ & $0.8868^{* *}$ & $1.0918^{* *}$ & $0.9594^{* *}$ \\
\hline & $(0.5077)$ & $(0.4315)$ & $(0.4991)$ & $(0.4846)$ \\
\hline \multirow[t]{2}{*}{ Inemp } & $-0.2682^{* * *}$ & $-0.2103^{* * *}$ & $-0.2577^{* * *}$ & $-0.2412^{* * *}$ \\
\hline & $(0.0726)$ & $(0.0588)$ & $(0.0645)$ & $(0.0645)$ \\
\hline \multirow[t]{2}{*}{ Inpopden } & -0.0202 & -0.0127 & -0.0310 & -0.0140 \\
\hline & $(0.0584)$ & $(0.0539)$ & $(0.0608)$ & $(0.0577)$ \\
\hline \multirow[t]{2}{*}{ pbachelor } & 3.0596 & 2.6959 & 2.1600 & 2.4154 \\
\hline & (3.0795) & $(2.4492)$ & $(2.7071)$ & (2.6195) \\
\hline \multirow[t]{2}{*}{ amenity } & $0.1070^{*}$ & $0.1232^{* *}$ & 0.0741 & $0.1024^{*}$ \\
\hline & $(0.0610)$ & $(0.0540)$ & $(0.0584)$ & $(0.0564)$ \\
\hline \multirow[t]{2}{*}{$\ln H P$} & $0.2371^{*}$ & $0.2158^{* *}$ & $0.2538^{* *}$ & $0.2160^{*}$ \\
\hline & $(0.1252)$ & $(0.1085)$ & $(0.1156)$ & $(0.1123)$ \\
\hline \multirow[t]{2}{*}{ Indistance } & $0.1235^{* *}$ & 0.0774 & 0.0817 & $0.0924^{*}$ \\
\hline & $(0.0545)$ & $(0.0480)$ & $(0.0526)$ & $(0.0527)$ \\
\hline \multirow[t]{2}{*}{ secondary } & -0.0003 & & & \\
\hline & $(0.0044)$ & & & \\
\hline \multirow[t]{2}{*}{ tertiary } & -0.0032 & & & \\
\hline & $(0.0063)$ & & & \\
\hline \multirow[t]{2}{*}{$\Delta$ lnenterprise } & & $0.2220^{* * *}$ & & \\
\hline & & $(0.0570)$ & & \\
\hline \multirow[t]{2}{*}{ Innewenterprise } & & & $0.1032^{* * *}$ & \\
\hline & & & $(0.0388)$ & \\
\hline \multirow[t]{2}{*}{ Inwintertemp } & & & & 0.0104 \\
\hline & & & & $(0.1021)$ \\
\hline \multirow[t]{2}{*}{ Insummertemp } & & & & 0.3440 \\
\hline & & & & $(0.3651)$ \\
\hline \multirow[t]{2}{*}{ east } & $0.4801^{* * *}$ & $0.3540^{* * *}$ & $0.2861^{*}$ & $0.3789^{* * *}$ \\
\hline & $(0.1342)$ & $(0.1112)$ & $(0.1497)$ & $(0.1244)$ \\
\hline \multirow[t]{2}{*}{ middle } & $0.1724^{*}$ & 0.0773 & 0.0724 & 0.1145 \\
\hline & $(0.0945)$ & $(0.0836)$ & $(0.0932)$ & $(0.0905)$ \\
\hline \multirow[t]{2}{*}{ _cons } & $-1.9317^{*}$ & $-1.6024^{*}$ & $-2.1485^{* *}$ & -2.5917 \\
\hline & $(0.9957)$ & $(0.8945)$ & $(0.9571)$ & (1.5976) \\
\hline First-stage stat. & 15.106 & 15.690 & 14.583 & 17.555 \\
\hline maximum 2SLS relative & $<15 \%$ & $<15 \%$ & $<15 \%$ & $<15 \%$ \\
\hline Over-id test & 0.4418 & 0.2131 & 0.2886 & 0.6225 \\
\hline DWH test & 0.0001 & 0.0073 & 0.0022 & 0.0051 \\
\hline Observations & 252 & 251 & 252 & 252 \\
\hline
\end{tabular}

Notes: The dependent variable is the change in the log of employment between 2003 and 2013. The coefficient of interest is the natural log of legal FARR. The additional control variables in column (1) - (4) are the value added of secondary and tertiary industries as a share of the regional GDP (secondary \& tertiary), the change in the log of the number of enterprises between 2003 and 2013 ( $\Delta$ Inenterprise), the log of the total number of new enterprises (Innewenterprise) and the log of winter and summer temperatures (Inwintertemp \& Insummertemp). The estimation method is the two-stage least squares (2SLS). Robust standard errors are in parentheses. *, **, *** represent statistical significance at the $10 \%, 5 \%$, and $1 \%$ levels respectively. 
Table 7: Robustness Test: Additional instruments

\begin{tabular}{|c|c|c|c|c|c|c|c|}
\hline & $(1)$ & $(2)$ & (3) & (4) & (5) & (6) & (7) \\
\hline & Batch 1 & Batch 2 & Batch 3 & Batch 4 & Batch 5 & Batch 6 & Batch 7 \\
\hline & \multicolumn{7}{|c|}{ Second-stage Regression } \\
\hline \multirow[t]{2}{*}{$\operatorname{lnFARR}$} & $1.3442^{* * * *}$ & $1.3557^{* * *}$ & $1.2859^{* *}$ & $1.2429^{* *}$ & $1.2633^{* *}$ & $1.0505^{* *}$ & $1.0261^{* *}$ \\
\hline & $(0.5168)$ & $(0.5206)$ & $(0.5076)$ & $(0.4916)$ & $(0.5019)$ & $(0.4711)$ & $(0.4683)$ \\
\hline \multirow[t]{2}{*}{ Inemp } & $-0.2563^{* * *}$ & $-0.2564^{* * *}$ & $-0.2558^{* * *}$ & $-0.2554^{* * *}$ & $-0.2556^{* * *}$ & $-0.2539^{* * *}$ & $-0.2537^{* * *}$ \\
\hline & $(0.0688)$ & $(0.0689)$ & $(0.0679)$ & $(0.0673)$ & $(0.0676)$ & $(0.0649)$ & $(0.0647)$ \\
\hline \multirow[t]{2}{*}{ Inpopden } & -0.0238 & -0.0246 & -0.0197 & -0.0167 & -0.0182 & -0.0033 & -0.0016 \\
\hline & $(0.0636)$ & $(0.0636)$ & $(0.0625)$ & $(0.0612)$ & $(0.0620)$ & $(0.0593)$ & $(0.0589)$ \\
\hline \multirow[t]{2}{*}{ pbachelor } & 2.5603 & 2.5680 & 2.5213 & 2.4925 & 2.5062 & 2.3639 & 2.3475 \\
\hline & $(2.8378)$ & $(2.8388)$ & $(2.8023)$ & $(2.7753)$ & (2.7895) & (2.6943) & (2.6829) \\
\hline \multirow[t]{2}{*}{ amenity } & $0.1002^{*}$ & 0.0998 & $0.1020^{*}$ & $0.1033^{*}$ & $0.1027^{*}$ & $0.1092^{*}$ & 0.1099* \\
\hline & $(0.0608)$ & $(0.0610)$ & $(0.0601)$ & $(0.0596)$ & (0.0597) & $(0.0576)$ & $(0.0572)$ \\
\hline \multirow[t]{2}{*}{$\ln H P$} & $0.2187^{*}$ & $0.2190^{*}$ & $0.2175^{*}$ & $0.2166^{*}$ & $0.2170^{*}$ & $0.2125^{*}$ & $0.2120^{*}$ \\
\hline & $(0.1183)$ & $(0.1185)$ & $(0.1170)$ & $(0.1162)$ & (0.1165) & $(0.1126)$ & $(0.1122)$ \\
\hline \multirow[t]{2}{*}{ Indistance } & $0.1237^{* *}$ & $0.1245^{* *}$ & $0.1198^{* *}$ & $0.1170^{* *}$ & $0.1183^{* *}$ & $0.1042^{* *}$ & $0.1026^{* *}$ \\
\hline & $(0.0538)$ & $(0.0540)$ & (0.0528) & $(0.0518)$ & $(0.0523)$ & $(0.0501)$ & $(0.0505)$ \\
\hline \multirow[t]{2}{*}{ east } & $0.4840^{* * * *}$ & $0.4863^{* * *}$ & $0.4719^{* * *}$ & $0.4631^{* * *}$ & $0.4673^{* * *}$ & $0.4233^{* * *}$ & $0.4183^{* * *}$ \\
\hline & $(0.1375)$ & $(0.1374)$ & $(0.1331)$ & $(0.1288)$ & (0.1317) & $(0.1215)$ & $(0.1197)$ \\
\hline \multirow[t]{2}{*}{ middle } & $0.1711^{*}$ & $0.1724^{*}$ & $0.1645^{*}$ & $0.1596^{*}$ & $0.1619^{*}$ & 0.1378 & 0.1350 \\
\hline & $(0.0932)$ & $(0.0937)$ & $(0.0919)$ & $(0.0906)$ & $(0.0914)$ & $(0.0868)$ & $(0.0865)$ \\
\hline \multirow[t]{3}{*}{ _cons } & $-1.9117^{* *}$ & $-1.9222^{* *}$ & $-1.8583^{*}$ & $-1.8190^{*}$ & $-1.8377^{*}$ & $-1.6430^{*}$ & $-1.6207^{*}$ \\
\hline & $(0.9669)$ & $(0.9689)$ & $(0.9510)$ & $(0.9437)$ & $(0.9466)$ & $(0.9038)$ & $(0.9019)$ \\
\hline & \multicolumn{7}{|c|}{ First-stage Regression } \\
\hline \multirow[t]{2}{*}{ latitude } & $-0.0076^{* * *}$ & $-0.0076^{* * *}$ & $-0.0077^{* * *}$ & $-0.0078^{* * * *}$ & $-0.0078^{* * *}$ & $-0.0079^{* * *}$ & $-0.0079^{* * *}$ \\
\hline & $(0.0019)$ & $(0.0019)$ & $(0.0019)$ & $(0.0019)$ & $(0.0019)$ & $(0.0019)$ & $(0.0019)$ \\
\hline \multirow[t]{2}{*}{ intensity } & $-0.0571^{* * *}$ & $-0.0561^{* * *}$ & $-0.0554^{* * *}$ & $-0.0540^{* *}$ & $-0.0545^{* *}$ & $-0.0537^{* *}$ & $-0.0531^{* *}$ \\
\hline & $(0.0208)$ & $(0.0209)$ & $(0.0210)$ & $(0.0211)$ & $(0.0210)$ & $(0.0210)$ & $(0.0210)$ \\
\hline \multirow[t]{2}{*}{ number } & 0.0102 & -0.0007 & -0.0056 & -0.0091 & -0.0051 & -0.0050 & $-0.0038^{*}$ \\
\hline & $(0.0149)$ & $(0.0145)$ & $(0.0094)$ & $(0.0076)$ & $(0.0056)$ & $(0.0034)$ & $(0.0023)$ \\
\hline \multicolumn{8}{|l|}{ Instruments: } \\
\hline latitude & $\mathrm{Y}$ & $\mathrm{Y}$ & $\mathrm{Y}$ & $\mathrm{Y}$ & $\mathrm{Y}$ & $\mathrm{Y}$ & $\mathrm{Y}$ \\
\hline intensity & $\mathrm{Y}$ & $\mathrm{Y}$ & $\mathrm{Y}$ & $\mathrm{Y}$ & $\mathrm{Y}$ & $\mathrm{Y}$ & $\mathrm{Y}$ \\
\hline number & $\mathrm{Y}$ & $\mathrm{Y}$ & $\mathrm{Y}$ & $\mathrm{Y}$ & $\mathrm{Y}$ & $\mathrm{Y}$ & $\mathrm{Y}$ \\
\hline First-stage stat. & 9.807 & 9.620 & 9.635 & 10.110 & 9.807 & 10.082 & 10.204 \\
\hline maximum 2SLS & $<10 \%$ & $<10 \%$ & $<10 \%$ & $<10 \%$ & $<10 \%$ & $<10 \%$ & $<10 \%$ \\
\hline Over-id test & 0.7270 & 0.6790 & 0.3868 & 0.4046 & 0.3649 & 0.0546 & 0.0636 \\
\hline DWH test & 0.0003 & 0.0003 & 0.0004 & 0.0004 & 0.0004 & 0.0020 & 0.0013 \\
\hline Observations & 252 & 252 & 252 & 252 & 252 & 252 & 252 \\
\hline
\end{tabular}

Notes: The dependent variable is the change in the log of employment between 2003 and 2013. The coefficient of interest is the natural log of legal FARR. The estimation method is the two-stage least squares (2SLS). The additional instruments are the different batches of the number of designated historical and cultural sites (DHCS) announced to be protected in (and before) 1961 (Batch1), 1982 (Batch2), 1988 (Batch3), 1996 (Batch4), 2001 (Batch5), 2006 (Batch6) and 2013 (Batch7). Robust standard errors are in parentheses. *, **, *** represent statistical significance at the $10 \%, 5 \%$, and $1 \%$ levels respectively. 
Table 8: Robustness Test: Additional control variables

\begin{tabular}{|c|c|c|c|c|c|}
\hline & (1) & $(2)$ & (3) & (4) & (5) \\
\hline & Urban sprawl & Labor Demand1 & Labor Demand2 & Both1 & Both2 \\
\hline \multirow[t]{2}{*}{$\operatorname{lnFARR}$} & $1.4719^{* *}$ & $1.2497^{* *}$ & $1.2013^{* *}$ & $1.3488^{* *}$ & $1.2975^{* *}$ \\
\hline & $(0.5756)$ & $(0.5948)$ & $(0.5877)$ & $(0.6552)$ & $(0.6455)$ \\
\hline \multirow[t]{2}{*}{ Inemp } & $-0.2401^{* * *}$ & $-0.2413^{* * *}$ & $-0.2351^{* * *}$ & $-0.2238^{* * *}$ & $-0.2175^{* * *}$ \\
\hline & $(0.0685)$ & $(0.0779)$ & $(0.0771)$ & $(0.0764)$ & $(0.0757)$ \\
\hline \multirow[t]{2}{*}{ Inpopden } & 0.0000 & -0.0357 & -0.0400 & -0.0130 & -0.0177 \\
\hline & $(0.0611)$ & $(0.0597)$ & $(0.0592)$ & $(0.0593)$ & $(0.0588)$ \\
\hline \multirow[t]{2}{*}{ pbachelor } & 3.6655 & 2.1886 & 2.0576 & 3.2076 & 3.0634 \\
\hline & (3.0498) & $(2.9432)$ & (2.8995) & (3.2186) & (3.1568) \\
\hline \multirow[t]{2}{*}{ amenity } & $0.1097^{*}$ & 0.0943 & 0.0912 & $0.1033^{*}$ & 0.0999 \\
\hline & $(0.0620)$ & $(0.0612)$ & $(0.0605)$ & $(0.0625)$ & $(0.0618)$ \\
\hline \multirow[t]{2}{*}{$\ln H P$} & $0.2440^{* *}$ & $0.2091^{*}$ & $0.2026^{*}$ & $0.2322^{*}$ & $0.2251^{*}$ \\
\hline & $(0.1219)$ & $(0.1145)$ & $(0.1131)$ & $(0.1188)$ & $(0.1176)$ \\
\hline \multirow[t]{2}{*}{ Indistance } & $0.1178^{* *}$ & 0.1099* & $0.1035^{*}$ & 0.1017 & 0.0951 \\
\hline & $(0.0543)$ & $(0.0629)$ & $(0.0620)$ & $(0.0622)$ & $(0.0613)$ \\
\hline \multirow[t]{2}{*}{ sprawl } & $1.2876^{*}$ & & & $1.2485^{*}$ & $1.2353^{*}$ \\
\hline & $(0.7580)$ & & & $(0.7520)$ & $(0.7332)$ \\
\hline \multirow[t]{2}{*}{ Bartik1 } & & 0.2627 & & 0.2934 & \\
\hline & & $(0.4576)$ & & $(0.4713)$ & \\
\hline \multirow[t]{2}{*}{ Bartik2 } & & & 0.3754 & & 0.4094 \\
\hline & & & $(0.4537)$ & & $(0.4671)$ \\
\hline \multirow[t]{2}{*}{ east } & $0.4718^{* * *}$ & $0.4809^{* * *}$ & $0.4775^{* * *}$ & $0.4660^{* * *}$ & $0.4625^{* * *}$ \\
\hline & $(0.1364)$ & $(0.1367)$ & $(0.1354)$ & $(0.1352)$ & $(0.1339)$ \\
\hline \multirow[t]{2}{*}{ middle } & $0.1572^{*}$ & $0.1747^{*}$ & $0.1754^{*}$ & $0.1601^{*}$ & $0.1608^{*}$ \\
\hline & $(0.0949)$ & $(0.0919)$ & $(0.0911)$ & $(0.0931)$ & $(0.0923)$ \\
\hline \multirow[t]{2}{*}{ _cons } & $-2.9946^{* *}$ & -1.6635 & $-1.8063^{*}$ & $-2.6720^{*}$ & $-2.8234^{* *}$ \\
\hline & $(1.2406)$ & (1.0191) & $(0.9343)$ & (1.3981) & $(1.2411)$ \\
\hline First-stage stat. & 12.663 & 13.288 & 13.307 & 11.602 & 11.635 \\
\hline maximum 2SLS & $<15 \%$ & $<15 \%$ & $<15 \%$ & $<15 \%$ & $<15 \%$ \\
\hline Over-id test & 0.4672 & 0.4692 & 0.4835 & 0.5064 & 0.5223 \\
\hline DWH test & 0.0003 & 0.0024 & 0.0030 & 0.0025 & 0.0031 \\
\hline Observation & 252 & 252 & 252 & 252 & 252 \\
\hline
\end{tabular}

Notes: The dependent variable is the change in the log of employment between 2003 and 2013. The coefficient of interest is the natural log of legal FARR. The estimation method is the two-stage least squares (2SLS). The additional control variables in column (1) - (3) are the urban sprawl index, Bartik index1 (Bartik1) and Bartik index2 (Bartik2). We calculate labour demand shocks by using the two forms of Bartik index. The additional control variables in columns (4) are urban sprawl index and Bartik index1, and in columns (5) are the urban sprawl index and Bartik index2. Robust standard errors are in parentheses. ${ }^{*}, *$, ${ }^{* * *}$ represent statistical significance at the $10 \%, 5 \%$, and $1 \%$ levels respectively. 
Table 9: Robustness Test: Considering mobility of Labour

\begin{tabular}{|c|c|c|c|}
\hline & $(1)$ & $(2)$ & (3) \\
\hline & \multicolumn{3}{|c|}{ Control lnFARR in Nearby Citys } \\
\hline & Within100km & Within $200 \mathrm{~km}$ & Within $300 \mathrm{~km}$ \\
\hline \multirow[t]{2}{*}{$\operatorname{lnFARR}$} & $3.3132^{* *}$ & $3.4361^{*}$ & $3.8992^{*}$ \\
\hline & (1.6101) & $(1.8426)$ & $(2.0645)$ \\
\hline \multirow[t]{2}{*}{ Inemp } & $-0.1839^{*}$ & $-0.2837^{* * *}$ & $-0.2732^{* *}$ \\
\hline & $(0.1003)$ & $(0.0967)$ & $(0.1116)$ \\
\hline \multirow[t]{2}{*}{ Inpopden } & -0.0680 & -0.0632 & -0.1090 \\
\hline & $(0.1096)$ & $(0.1063)$ & $(0.1255)$ \\
\hline \multirow[t]{2}{*}{ amenity } & -4.2652 & -0.3993 & -1.6296 \\
\hline & $(4.4989)$ & $(3.8692)$ & $(4.5519)$ \\
\hline \multirow[t]{2}{*}{ pbachelor } & 0.0452 & 0.0956 & 0.1171 \\
\hline & $(0.1178)$ & $(0.0928)$ & $(0.1011)$ \\
\hline \multirow[t]{2}{*}{$\ln H P$} & 0.1852 & 0.1919 & 0.1747 \\
\hline & $(0.1829)$ & $(0.1730)$ & $(0.1881)$ \\
\hline \multirow[t]{2}{*}{ Indistance } & 0.1270 & 0.1007 & 0.1590 \\
\hline & $(0.0891)$ & $(0.0730)$ & $(0.0977)$ \\
\hline \multirow[t]{2}{*}{ InspatialFARR } & $-2.1522^{* *}$ & $-3.0039^{* *}$ & $-3.2800^{* *}$ \\
\hline & $(0.9265)$ & $(1.4136)$ & $(1.5867)$ \\
\hline \multirow[t]{2}{*}{ east } & $0.4966^{* *}$ & $0.4843^{* *}$ & $0.5928^{* *}$ \\
\hline & $(0.2397)$ & $(0.2364)$ & $(0.2912)$ \\
\hline \multirow[t]{2}{*}{ middle } & 0.1330 & 0.1253 & 0.1901 \\
\hline & $(0.1578)$ & $(0.1294)$ & $(0.1592)$ \\
\hline \multirow[t]{2}{*}{ _cons } & -1.2032 & -0.3117 & -0.2556 \\
\hline & (1.4517) & (1.2861) & (1.4514) \\
\hline Observations & 191 & 248 & 251 \\
\hline
\end{tabular}

Notes: The dependent variable is the change in the log of employment between 2003 and 2013. The coefficient of interest is the natural log of legal FARR. The estimation method is the two-stage least squares (2SLS). InspatialFARR is an additional control which is the average legal FARR of a city when all its neighbouring cities within $100 \mathrm{~km}, 200 \mathrm{~km}$ or $300 \mathrm{~km}$ are included in the calculation. Column 1 shows the results when controlling the average legal FARR for neighbouring cities within $100 \mathrm{~km}$, Column 2 within $200 \mathrm{~km}$, and Column 3 within $300 \mathrm{~km}$. Robust standard errors are in parentheses. *, **, *** represent statistical significance at the $10 \%, 5 \%$, and $1 \%$ levels respectively. 
Table 10: Heterogeneity analysis of city size

\begin{tabular}{|c|c|c|c|c|c|c|}
\hline & $(1)$ & $(2)$ & (3) & (4) & (5) & (6) \\
\hline & $\begin{array}{c}\text { Permanent } \\
\text { pop2000 }\end{array}$ & $\begin{array}{c}\text { Household } \\
\text { pop2000 }\end{array}$ & $\begin{array}{l}\text { Permanent } \\
\text { pop2001 }\end{array}$ & $\begin{array}{c}\text { Household } \\
\text { pop2001 }\end{array}$ & $\begin{array}{c}\text { Permanent } \\
\text { pop2002 }\end{array}$ & $\begin{array}{c}\text { Household } \\
\text { pop2002 }\end{array}$ \\
\hline \multirow[t]{2}{*}{$\operatorname{lnFARR}$} & -0.1016 & -0.3741 & -0.0393 & 0.5131 & -0.0594 & 0.0200 \\
\hline & $(0.7018)$ & $(0.6756)$ & $(0.7018)$ & $(0.5702)$ & $(0.6958)$ & $(0.5538)$ \\
\hline \multirow[t]{2}{*}{$\ln p o p \times \ln F A R R$} & $0.3057^{* * *}$ & $0.2116^{* * *}$ & $0.2852^{* * *}$ & $0.2656^{* * *}$ & $0.2857^{* * *}$ & $0.2741^{* * *}$ \\
\hline & $(0.0965)$ & $(0.0711)$ & $(0.0904)$ & $(0.0830)$ & (0.0889) & $(0.0788)$ \\
\hline \multirow[t]{2}{*}{ Inemp } & $-0.4631^{* * *}$ & $-0.3867^{* * *}$ & $-0.4510^{* * *}$ & $-0.4483^{* * *}$ & $-0.4484^{* * *}$ & $-0.4510^{* * *}$ \\
\hline & $(0.0944)$ & $(0.0790)$ & $(0.0922)$ & $(0.0863)$ & $(0.0909)$ & $(0.0835)$ \\
\hline \multirow[t]{2}{*}{ Inpopden } & -0.0384 & -0.0222 & -0.0308 & -0.0429 & -0.0285 & -0.0096 \\
\hline & $(0.0560)$ & (0.0619) & $(0.0564)$ & $(0.0642)$ & $(0.0565)$ & $(0.0601)$ \\
\hline \multirow[t]{2}{*}{ pbachelor } & 3.1475 & 3.3077 & 3.2674 & 3.5902 & 3.2331 & 3.3849 \\
\hline & $(2.7780)$ & (2.9033) & $(2.7751)$ & (3.0548) & (2.7736) & $(2.8320)$ \\
\hline \multirow[t]{2}{*}{ amenity } & 0.0837 & 0.0788 & 0.0813 & 0.0580 & 0.0781 & 0.0826 \\
\hline & $(0.0603)$ & (0.0609) & $(0.0598)$ & $(0.0666)$ & $(0.0596)$ & $(0.0605)$ \\
\hline \multirow[t]{2}{*}{$\ln H P$} & $0.2663^{* *}$ & $0.2886^{* *}$ & $0.2774^{* *}$ & $0.3442^{* * *}$ & $0.2783^{* *}$ & $0.3322^{* * *}$ \\
\hline & $(0.1182)$ & $(0.1276)$ & $(0.1187)$ & (0.1293) & $(0.1184)$ & $(0.1260)$ \\
\hline \multirow[t]{2}{*}{ Indistance } & 0.0863 & $0.0888^{*}$ & 0.0801 & $0.1244^{* *}$ & 0.0784 & 0.0869 \\
\hline & $(0.0536)$ & $(0.0533)$ & $(0.0549)$ & $(0.0601)$ & $(0.0549)$ & $(0.0530)$ \\
\hline \multirow[t]{2}{*}{ east } & $0.4575^{* * *}$ & $0.5728^{* * *}$ & $0.4598^{* * *}$ & $0.5896^{* * *}$ & $0.4590^{* * *}$ & $0.4992^{* * *}$ \\
\hline & $(0.1277)$ & $(0.1441)$ & $(0.1282)$ & $(0.1606)$ & $(0.1277)$ & $(0.1325)$ \\
\hline \multirow[t]{2}{*}{ middle } & $0.1719^{* *}$ & $0.2448^{* *}$ & $0.1715^{* *}$ & $0.2346^{* *}$ & $0.1711^{* *}$ & $0.2097^{* *}$ \\
\hline & $(0.0862)$ & $(0.1022)$ & $(0.0865)$ & $(0.1108)$ & $(0.0863)$ & $(0.0926)$ \\
\hline \multirow[t]{2}{*}{ _cons } & -1.3026 & -1.2654 & -1.4391 & $-2.5182^{* *}$ & -1.4512 & $-2.0976^{* *}$ \\
\hline & $(0.9457)$ & $(0.9231)$ & $(0.9406)$ & (1.0687) & $(0.9402)$ & (0.9609) \\
\hline Observations & 252 & 252 & 252 & 244 & 252 & 252 \\
\hline
\end{tabular}

Notes: This table adds the interaction of $\ln F A R R$ and population. Population can be permanent population or registered household population. Column 1, 3 and 5 use the permanent population in the regressions and 2, 4 and 6 the registered household population. Population are lagged one, two or three years. Robust standard errors are in parentheses. *, **, *** represent statistical significance at the $10 \%, 5 \%$ and $1 \%$ levels respectively. 
Table 11: Heterogeneity analysis of industrial characteristics and corporate ownerships

\begin{tabular}{|c|c|c|c|}
\hline & (1) & (2) & (3) \\
\hline & Industry heterogeneity & Labor-intensive & Ownership heterogeneity \\
\hline \multirow[t]{2}{*}{$\operatorname{lnFARR}$} & $0.6610^{*}$ & $2.3489^{* * * *}$ & -0.9495 \\
\hline & $(0.3821)$ & $(0.8748)$ & $(1.1570)$ \\
\hline \multirow[t]{2}{*}{ Manudum $\times \ln F A R R$} & $2.5226^{* * *}$ & & \\
\hline & $(0.7756)$ & & \\
\hline \multirow[t]{2}{*}{ Manudum } & $-2.7448^{* * *}$ & & \\
\hline & $(0.7463)$ & & \\
\hline \multirow[t]{2}{*}{ Labdum $\times \ln F A R R$} & & $1.3679^{* *}$ & \\
\hline & & $(0.6415)$ & \\
\hline \multirow[t]{2}{*}{ Lobardum } & & $-1.7372^{* * *}$ & \\
\hline & & $(0.6218)$ & \\
\hline Privately-owneddum & & & $5.2882^{* * *}$ \\
\hline$\times \ln F A R R$ & & & $(1.7429)$ \\
\hline \multirow[t]{2}{*}{ Privately-owneddum } & & & $-4.3393^{* *}$ \\
\hline & & & $(1.7200)$ \\
\hline Foreign-owneddum & & & $4.0867^{* *}$ \\
\hline$\times \ln F A R R$ & & & $(2.0444)$ \\
\hline \multirow[t]{2}{*}{ Foreign-owneddum } & & & $-3.4390^{*}$ \\
\hline & & & $(1.9660)$ \\
\hline \multirow[t]{2}{*}{ _cons } & $-1.9393^{* *}$ & 1.5505 & -1.3074 \\
\hline & $(0.9279)$ & $(1.6350)$ & $(2.3143)$ \\
\hline Control Variables & $\mathrm{Y}$ & $\mathrm{Y}$ & $\mathrm{Y}$ \\
\hline Observations & 524 & 517 & 685 \\
\hline
\end{tabular}

Notes: In Column 1, manudum*InFARR is the interaction variable between FARR and the dummy variable representing the manufacturing sector. In Column 2, Labdum*LnFARR is the interaction variable between FARR and the dummy variable representing labour-intensive industries. In Column 3 , Privately*LnFARR is the interaction variable between FARR and the dummy variable representing privately-owned firms and in Column 4, Foreign*LnFARR is the interaction variable between FARR and the dummy variable representing foreign-owned firms. Robust standard errors are in parentheses. $*, * *,{ }^{* * *}$ represent statistical significance at the $10 \%, 5 \%$ and $1 \%$ levels respectively. 
Table 12

Instrumental variable quantile regression

\begin{tabular}{|c|c|c|c|c|c|c|c|}
\hline & $(1)$ & $(2)$ & (3) & (4) & (5) & (6) & $(7)$ \\
\hline & \multicolumn{7}{|c|}{ Quantiles of the conditional growth distribution } \\
\hline & 0.10 & 0.15 & 0.25 & 0.50 & 0.75 & 0.85 & 0.90 \\
\hline $\operatorname{lnFARR}$ & $\begin{array}{l}1.5985^{* *} \\
(0.7583)\end{array}$ & $\begin{array}{c}2.7960^{*} \\
(1.4288)\end{array}$ & $\begin{array}{l}2.9117^{* *} \\
(1.2112)\end{array}$ & $\begin{array}{c}0.7998^{*} \\
(0.4205)\end{array}$ & $\begin{array}{l}1.1380^{* *} \\
(0.4709)\end{array}$ & $\begin{array}{c}0.7555 \\
(0.4694)\end{array}$ & $\begin{array}{c}0.6238 \\
(0.4595)\end{array}$ \\
\hline Inemp & $\begin{array}{l}-0.0887 \\
(0.1347)\end{array}$ & $\begin{array}{l}-0.1423 \\
(0.1355)\end{array}$ & $\begin{array}{c}-0.3901^{* * *} \\
(0.1466)\end{array}$ & $\begin{array}{c}-0.1978^{* *} \\
(0.0801)\end{array}$ & $\begin{array}{c}-0.3111^{* * *} \\
(0.0902)\end{array}$ & $\begin{array}{c}-0.4034^{* * *} \\
(0.0944)\end{array}$ & $\begin{array}{c}-0.4601^{* * *} \\
(0.0972)\end{array}$ \\
\hline Inpopden & $\begin{array}{l}-0.0040 \\
(0.0857)\end{array}$ & $\begin{array}{c}-0.0833 \\
(0.0915)\end{array}$ & $\begin{array}{l}-0.1361 \\
(0.0917)\end{array}$ & $\begin{array}{c}-0.0864 \\
(0.0741)\end{array}$ & $\begin{array}{l}-0.0085 \\
(0.0800)\end{array}$ & $\begin{array}{c}0.0986 \\
(0.0811)\end{array}$ & $\begin{array}{c}0.1203 \\
(0.0825)\end{array}$ \\
\hline pbachelor & $\begin{array}{l}-2.1488 \\
(4.0647)\end{array}$ & $\begin{array}{l}-2.9356 \\
(5.1250)\end{array}$ & $\begin{array}{c}6.7222 \\
(5.6843)\end{array}$ & $\begin{array}{c}2.6812 \\
(3.0082)\end{array}$ & $\begin{array}{c}3.5408 \\
(2.8517)\end{array}$ & $\begin{array}{c}4.6002 \\
(2.9369)\end{array}$ & $\begin{array}{l}6.1748^{* *} \\
(2.8709)\end{array}$ \\
\hline amenity & $\begin{array}{c}0.2123^{*} \\
(0.1187)\end{array}$ & $\begin{array}{c}0.1207 \\
(0.1254)\end{array}$ & $\begin{array}{c}0.1718 \\
(0.1301)\end{array}$ & $\begin{array}{c}0.0900 \\
(0.0822)\end{array}$ & $\begin{array}{c}0.0300 \\
(0.0738)\end{array}$ & $\begin{array}{c}0.0834 \\
(0.0821)\end{array}$ & $\begin{array}{c}0.0614 \\
(0.0763)\end{array}$ \\
\hline $\ln H P$ & $\begin{array}{c}0.1828 \\
(0.3109)\end{array}$ & $\begin{array}{c}0.2647 \\
(0.3047)\end{array}$ & $\begin{array}{c}0.3020 \\
(0.2916)\end{array}$ & $\begin{array}{c}0.1242 \\
(0.1409)\end{array}$ & $\begin{array}{c}0.2378^{*} \\
(0.1414)\end{array}$ & $\begin{array}{l}0.3172^{* *} \\
(0.1546)\end{array}$ & $\begin{array}{l}0.3147^{* *} \\
(0.1538)\end{array}$ \\
\hline Indistance & $\begin{array}{c}0.0541 \\
(0.0915)\end{array}$ & $\begin{array}{c}0.1572 \\
(0.1283)\end{array}$ & $\begin{array}{c}0.1766 \\
(0.1092)\end{array}$ & $\begin{array}{c}0.0597 \\
(0.0580)\end{array}$ & $\begin{array}{c}0.2085^{* * *} \\
(0.0777)\end{array}$ & $\begin{array}{c}0.1259^{*} \\
(0.0737)\end{array}$ & $\begin{array}{c}0.1423^{*} \\
(0.0792)\end{array}$ \\
\hline east & $\begin{array}{c}0.4597 \\
(0.3153)\end{array}$ & $\begin{array}{c}0.5565 \\
(0.4085)\end{array}$ & $\begin{array}{c}0.6809^{*} \\
(0.3561)\end{array}$ & $\begin{array}{c}0.4423^{* * *} \\
(0.1431)\end{array}$ & $\begin{array}{c}0.5254^{* * *} \\
(0.1765)\end{array}$ & $\begin{array}{c}0.3466^{*} \\
(0.1920)\end{array}$ & $\begin{array}{l}0.4788^{* *} \\
(0.2271)\end{array}$ \\
\hline middle & $\begin{array}{c}0.2171 \\
(0.2252)\end{array}$ & $\begin{array}{c}0.3253 \\
(0.3049)\end{array}$ & $\begin{array}{c}0.3739 \\
(0.2672)\end{array}$ & $\begin{array}{c}0.1680 \\
(0.1272)\end{array}$ & $\begin{array}{c}0.1577 \\
(0.1212)\end{array}$ & $\begin{array}{c}0.0714 \\
(0.1042)\end{array}$ & $\begin{array}{c}0.1031 \\
(0.1020)\end{array}$ \\
\hline _cons & $\begin{array}{l}-2.5760 \\
(1.8395)\end{array}$ & $\begin{array}{l}-4.2671^{*} \\
(2.3883)\end{array}$ & $\begin{array}{l}-4.0954^{*} \\
(2.4251)\end{array}$ & $\begin{array}{l}-0.3257 \\
(1.1394)\end{array}$ & $\begin{array}{l}-1.7409 \\
(1.1049)\end{array}$ & $\begin{array}{l}-2.0306^{*} \\
(1.1039)\end{array}$ & $\begin{array}{l}-2.0347^{*} \\
(1.0841)\end{array}$ \\
\hline Observations & 252 & 252 & 252 & 252 & 252 & 252 & 252 \\
\hline
\end{tabular}

Notes: Column (1) - (7) represent the result of IVQR at the $0.10,0.15,0.25,0.50,0.75,0.80$, and 0.90 percentiles. Robust standard errors are in parentheses. *, **, *** represent statistical significance at the $10 \%, 5 \%$ and $1 \%$ levels respectively. 
Appendix Table 1

Robustness Test: Changing different estimation techniques

\begin{tabular}{lcccc}
\hline & $(1)$ & $(2)$ & $(3)$ & $(4)$ \\
\cline { 2 - 4 } InFARR & LIML & GMM & CFM & Plausibility \\
Inemp & $1.3849^{* * *}$ & $1.3586^{* * * *}$ & $1.3854^{* * *}$ & $1.3580^{* * *}$ \\
& $(0.5325)$ & $(0.5209)$ & $(0.4286)$ & $(0.5274)$ \\
Inpopden & $-0.2566^{* * *}$ & $-0.2503^{* * *}$ & $-0.2529^{* * *}$ & $-0.2564^{* * *}$ \\
& $(0.0694)$ & $(0.0685)$ & $(0.0633)$ & $(0.0691)$ \\
pbachelor & -0.0267 & -0.0243 & -0.0368 & -0.0248 \\
& $(0.0644)$ & $(0.0636)$ & $(0.0580)$ & $(0.0638)$ \\
amenity & 2.5875 & 2.6267 & 2.8928 & 2.5695 \\
InHP & $(2.8547)$ & $(2.8392)$ & $(2.4310)$ & $(2.8402)$ \\
& 0.0990 & 0.0917 & $0.0936^{*}$ & 0.0998 \\
Indistance & $(0.0614)$ & $(0.0601)$ & $(0.0551)$ & $(0.0610)$ \\
& $0.2196^{*}$ & $0.2206^{*}$ & $0.2120^{*}$ & $0.2190^{*}$ \\
east & $(0.1191)$ & $(0.1185)$ & $(0.1085)$ & $(0.1186)$ \\
& $0.1264^{* *}$ & $0.1258^{* *}$ & $0.1274^{* * *}$ & $0.1246^{* *}$ \\
middle & $(0.0546)$ & $(0.0540)$ & $(0.0445)$ & $(0.0543)$ \\
& $0.4924^{* * *}$ & $0.4941^{* * *}$ & $0.4929^{* * *}$ & $0.4868^{* * *}$ \\
_cons & $(0.1401)$ & $(0.1373)$ & $(0.1006)$ & $(0.1385)$ \\
Observations & $0.1758^{*}$ & $0.1757^{*}$ & $0.1796^{* *}$ & $0.1727^{*}$
\end{tabular}

Notes: The dependent variable is the change in the log of employment between 2003 and 2013. The coefficient of interest is the natural log of legal FARR. The estimation methods in column (1) - (4) are respectively limited information maximum likelihood (LIML), generalized method of moments (GMM), control function method (CFM), and plausibly exogenous approach. Robust standard errors are in parentheses. ${ }^{*}, * *, * * *$ represent statistical significance at the $10 \%, 5 \%$ and $1 \%$ levels respectively. 


\section{Refenrences}

Angrist J D, Pischke J S. The credibility revolution in empirical economics: How better research design is taking the con out of econometrics[J]. Journal of economic perspectives, 2010, 24(2): 3-30.

Annez P C, Linn J F. An agenda for research on urbanization in developing countries: a summary of findings from a scoping exercise[M]. The World Bank, 2010.

Boyce R R. Changing patterns of urban land consumption[J]. The Professional Geographer, 1963, 15(2): 19-24.

Bartik T J. Who benefits from state and local economic development policies?[J]. W.E. Upjohn Institute For Employment Research, Kalamazoo, MI, 1991.

Bertaud A, Brueckner J K. Analyzing building-height restrictions: predicted impacts and welfare costs[J]. Regional Science and Urban Economics, 2005, 35(2): 109-125.

Bertaud A. Land markets, government interventions, and housing affordability[M]. Wolfensohn Center For Development at Brookings, 2010.

Barr J, Cohen J P. The floor area ratio gradient: New York City, 1890-2009[J]. Regional Science and Urban Economics, 2014, 48: 110-119.

Baum-Snow N, Ferreira F. Causal inference in urban and regional economics[M]. Handbook of regional and urban economics. Elsevier, 2015, 5: 3-68.

Brueckner J K. Urban sprawl: diagnosis and remedies[J]. International regional science review, 2000, 23(2): 160-171.

Brueckner J K, Sridhar K S. Measuring welfare gains from relaxation of land-use restrictions: The case of India's building-height limits[J]. Regional Science and Urban Economics, 2012, 42(6): 1061-1067.

Brueckner J K, Fu S, Gu Y, et al. Measuring the stringency of land use regulation: The case of China's building height limits[J]. Review of Economics and Statistics, 2017, 99(4): 663-677.

Brueckner J K, Singh R. Stringency of land-use regulation: Building heights in US cities[J]. Journal of Urban Economics, 2020: 103239.

Colwell P F, Sirmans C F. A comment on zoning, returns to scale, and the value of undeveloped land[J]. The Review of Economics and Statistics, 1993: 783-786.

Cunningham C R. Growth controls, real options, and land development[J]. The Review of Economics and Statistics, 2007, 89(2): 343-358.

Chernozhukov V, Hansen C. Instrumental quantile regression inference for structural and treatment effect models[J]. Journal of Econometrics, 2006, 132(2): 491-525.

Chen Y. Characterizing growth and form of fractal cities with allometric scaling exponents[J]. Discrete Dynamics in Nature and Society, 2010, 2010.

Combes P P, Duranton G, Gobillon L, et al. Estimating agglomeration economies with history, geology, and worker effects[M]. Agglomeration economics. University of Chicago Press, 2010: 15-66.

Combes P P, Gobillon L. The empirics of agglomeration economies[M]. Handbook of regional and urban economics. Elsevier, 2015, 5: 247-348. 
Conley T G, Hansen C B, Rossi P E. Plausibly exogenous[J]. Review of Economics and Statistics, 2012, 94(1): 260-272.

Cai H, Wang Z, Zhang Q. To build above the limit? Implementation of land use regulations in urban China[J]. Journal of Urban Economics, 2017, 98: 223-233.

Desmet K, Rossi-Hansberg E. Spatial growth and industry age[J]. Journal of Economic Theory, 2009, 144(6): 2477-2502.

Desmet K, Rossi-Hansberg E. Urban accounting and welfare[J]. American Economic Review, 2013, 103(6): 2296-2327.

Desmet K, Ghani E, O'Connell S, et al. The spatial development of India[J]. Journal of Regional Science, 2015, 55(1): 10-30.

Duranton G, Turner M A. Urban growth and transportation[J]. Review of Economic Studies, 2012, 79(4): 1407-1440.

Duranton G, Puga D. Urban land use[M]. Handbook of regional and urban economics. Elsevier, 2015, 5: 467-560.

Duranton G. Determinants of city growth in Colombia[J]. Papers in Regional Science, 2016, 95(1): 101131.

Diamond R. The determinants and welfare implications of US workers' diverging location choices by skill: 1980-2000[J]. American Economic Review, 2016, 106(3): 479-524.

Fu Y, Somerville C T. Site density restrictions: measurement and empirical analysis[J]. Journal of Urban Economics, 2001, 49(2): 404-423.

Fallah B, Partridge M, Olfert M R. Uncertain economic growth and sprawl: evidence from a stochastic growth approach[J]. The Annals of Regional Science, 2012, 49(3): 589-617.

Fesselmeyer E, Seah K Y S. The effect of localized density on housing prices in Singapore[J]. Regional Science and Urban Economics, 2018, 68(C): 304-315.

Faber B, Gaubert C. Tourism and economic development: evidence from Mexico's coastline[J]. American Economic Review, 2019, 109(6): 2245-93.

Glaeser E L, Kahn M E. Sprawl and urban growth[M]. Handbook of regional and urban economics. Elsevier, 2004, 4: 2481-2527.

Glaeser E L, Gyourko J, Saks R. Why is Manhattan so expensive? Regulation and the rise in housing prices[J]. The Journal of Law and Economics, 2005, 48(2): 331-369.

Glaeser E L, Schuetz J, Ward B. Regulation and the rise of housing prices in Greater Boston[J]. Cambridge: Rappaport Institute for Greater Boston, Harvard University and Boston: Pioneer Institute for Public Policy Research, 2006a.

Glaeser E L, Gyourko J, Saks R E. Urban growth and housing supply[J]. Journal of economic geography, 2006b, 6(1): 71-89.

Glaeser E L, Ward B A. The causes and consequences of land use regulation: Evidence from Greater Boston[J]. Journal of Urb an Economics, 2009, 65(3): 265-278. 
Glaeser E L, Kerr S P, Kerr W R. Entrepreneurship and urban growth: An empirical assessment with historical mines[J]. Review of Economics and Statistics, 2015, 97(2): 498-520.

Geshkov M V, DeSalvo J S. the Effect of Land - Use Controls on the Spatial Size of US Urbanized Areas[J]. Journal of Regional Science, 2012, 52(4): 648-675.

Gyourko J, Saiz A, Summers A. A new measure of the local regulatory environment for housing markets: The Wharton Residential Land Use Regulatory Index[J]. Urban Studies, 2008, 45(3): 693-729.

Gyourko J, Molloy R. Regulation and housing supply[M]. Handbook of regional and urban economics. Elsevier, 2015, 5: 1289-1337.

Hannah L, Kim K H, Mills E S. Land use controls and housing prices in Korea[J]. Urban Studies, 1993, 30(1): 147-156.

Hornbeck R, Moretti E. Who benefits from productivity growth? Direct and indirect effects of local TFP growth on wages, rents, and inequality[R]. National Bureau of Economic Research, 2018.

Hsieh C T, Moretti E. Housing constraints and spatial misallocation[J]. American Economic Journal: Macroeconomics, 2019, 11(2): 1-39.

Ihlanfeldt K R. The effect of land use regulation on housing and land prices[J]. Journal of Urban Economics, 2007, 61(3): 420-435.

Kahn M E, Vaughn R, Zasloff J. The housing market effects of discrete land use regulations: Evidence from the California coastal boundary zone[J]. Journal of Housing Economics, 2010, 19(4): 269-279.

Lall S V, Wang H G, Da Mata D. Do urban land regulations influence slum formation? Evidence from Brazilian cities[J]. Brazilian Association of Graduate Programs in Economics, 2007.

Long, Hualou, et al. "Socio-economic development and land-use change: Analysis of rural housing land transition in the Transect of the Yangtse River, China." Land Use Policy 24.1 (2007): 141-153.

Libecap G D, Lueck D. The demarcation of land and the role of coordinating property institutions[J]. Journal of Political Economy, 2011, 119(3): 426-467.

Liu X, Du C, Li S. Natural Geographical Constraints, Land Use Regulations and China's Housing Supply Elasticity[J]. Economic Research Journal, 2019, 54(4): 99-115 (in Chinese).

Lu J. Does Foreign Direct Investment Benefit Chinese Indigenous Firms? Effects and Channels[J]. Economic Research Journal, 2008, 6: 95-106 (in Chinese).

Mayer C J, Somerville C T. Land use regulation and new construction[J]. Regional Science and Urban Economics, 2000, 30(6): 639-662.

Nie H, Zhang Y, Jiang T. The Impact of R egional Corruption on Firm TFP in China[J]. China Soft Science, 2014, 37-48 (in Chinese).

Nunn N, Wantchekon L. The slave trade and the origins of mistrust in Africa[J]. American Economic Review, 2011, 101(7): 3221-52.

Qin M, Liu X, Li S. The Impact of Urban Sprawl on Regional Economic Growth—Empirical Researches Based on DMSP Night-Time Light Data[J]. China Economic Quartely, 2019, 18(2): 527-550 (in Chinese). 
Quigley J M, Raphael S, Rosenthal L A. Local land-use controls and demographic outcomes in a booming economy[J]. Urban Studies, 2004, 41(2): 389-421.

Rosen S. Wage-based indexes of urban quality of life[J]. Current issues in urban economics, 1979: 74-104.

Rothwell J T, Massey D S. Density zoning and class segregation in US metropolitan areas[J]. Social science quarterly, 2010, 91(5): 1123-1143.

Stock J, Yogo M. Asymptotic distributions of instrumental variables statistics with many instruments[J]. Identification and inference for econometric models: Essays in honor of Thomas Rothenberg, 2005: 109-120.

Sridhar K S. Density gradients and their determinants: Evidence from India[J]. Regional Science and Urban Economics, 2007, 37(3): 314-344.

Sridhar K S. Impact of land use regulations: Evidence from India’s cities[J]. Urban Studies, 2010, 47(7): 1541-1569.

Saks R E. Job creation and housing construction: Constraints on metropolitan area employment growth[J]. Journal of Urban Economics, 2008, 64(1): 178-195.

Saiz A. The geographic determinants of housing supply[J]. The Quarterly Journal of Economics, 2010, 125(3): 1253-1296.

Thorsnes P. Internalizing neighborhood externalities: the effect of subdivision size and zoning on residential lot prices[J]. Journal of Urban Economics, 2000, 48(3): 397-418.

Turner M A, Haughwout A, Van Der Klaauw W. Land use regulation and welfare[J]. Econometrica, 2014, 82(4): 1341-1403.

Tan Y, Wang Z, Zhang Q. Land-Use Regulation and the Intensive Margin of Housing Supply[J]. Journal of Urban Economics, 2020, 115: 103199.

Yu Y. Land-Use Regulation and Economic Development: Evidence from the Farmland Red Line Policy in China[R]. Columbia university working paper, 2019.

Wooldridge J M. Control function methods in applied econometrics[J]. Journal of Human Resources, 2015, 50(2): 420-445.

Zhang L, Wang X, Xu X. Fiscal Incentive, Political Incentive and Local Officials’ Land Supply[J]. China Industrial Economics, 2011, 04: 35-43(in Chinese). 